\title{
Diversity of functional traits of fleshy fruits in a species-rich Atlantic rain forest
}

\author{
Mauro Galetti ${ }^{1}$, Marco Aurélio Pizo ${ }^{2,4}$ \& Leonor Patrícia Cerdeira Morellato ${ }^{3}$ \\ ${ }^{1}$ Departamento de Ecologia, Universidade Estadual Paulista - UNESP, \\ CP 199, CEP 13506-900, Rio Claro, SP, Brazil \\ ${ }^{2}$ Departamento de Zoologia, Universidade Estadual Paulista - UNESP, \\ CP 199, CEP 13506-900, Rio Claro, SP, Brazil \\ ${ }^{3}$ Departamento de Botânica, Universidade Estadual Paulista - UNESP, \\ CP 199, CEP 13506-900, Rio Claro, SP, Brasil \\ ${ }^{4}$ Author for correspondence: Marco Aurélio Pizo, e-mail: pizo@rc.unesp.br
}

GALETTI, M., PIZO, M.A. \& MORELLATO, L.P.C. Diversity of functional traits of fleshy fruits in a species-rich Atlantic rain forest. Biota Neotrop. 11(1): http://www.biotaneotropica.org.br/v11n1/en/ abstract?article+bn02811012011.

\begin{abstract}
Production of vertebrate-dispersed fruits is the most common strategy of tropical woody plants to disperse their seeds. Few studies have documented community-wide variation of fruit morphology and chemistry of vertebrate-dispersed fruits in species-rich tropical communities. We examined the functional diversity of fruit morphological and chemical traits of 186 species representing 57 plant families in an undisturbed lowland plant community in the Atlantic rain forest of SE, Brazil. We were particularly interested in associating morphological and chemical fruit traits to their main seed dispersers, either birds, mammals or 'mixed' (i.e. fruits eaten by birds and mammals). The morphological and chemical traits of fruits at the study site generally resemble the patterns observed in fruits worldwide. Bird fruits tend to be smaller than mammal fruits, being colored black or red, whereas mammal fruits are often yellow or green. Mammal fruits are more variable than bird fruits in relation to morphological traits, while the reverse is true for chemical traits. Mixed fruits resemble bird fruits in the patterns of variation of morphological and chemical traits, suggesting that they are primarily bird-dispersed fruits that are also exploited by mammals. Mixed fruits are common in tropical forests, and represent an excellent opportunity to contrast the effectiveness of different functional groups of frugivores dispersing the same plant species.
\end{abstract}

Keywords: seed dispersal, frugivores, fruit syndromes, fruit chemical content.

GALETTI, M., PIZO, M.A. \& MORELLATO, L.P.C. Diversidade de características funcionais dos frutos carnosos em uma área de Mata Atlântica. Biota Neotrop. 11(1): http://www.biotaneotropica.org.br/v11n1/pt/ abstract?article+bn02811012011.

Resumo: A produção de frutos carnosos é a estratégia mais comum adotada por plantas arbóreas tropicais para dispersar suas sementes. Poucos estudos têm documentado variações em nível de comunidade na morfologia e composição química de frutos carnosos em comunidades tropicais ricas em espécie. Nós examinamos a diversidade funcional das características morfológicas e químicas dos frutos de 186 espécies, representando 57 famílias de plantas em uma área de planície coberta por Mata Atlântica bem preservada no sudeste do Brasil. Estávamos particularmente interessados em associar as características morfológicas e químicas dos frutos a seus principais dispersores de sementes: aves, mamíferos ou "misto" (i.e. frutos consumidos por aves e mamíferos). As características morfológicas e químicas dos frutos no geral se assemelharam a padrões observados em outras partes do mundo. Frutos consumidos por aves tendem a ser menores do que os frutos de mamíferos, apresentando predominantemente cor preta ou vermelha, enquanto os frutos de mamíferos são geralmente amarelos ou verdes. Frutos consumidos por mamíferos são mais variáveis do que os frutos de aves em relação às características morfológicas, enquanto o inverso é verdadeiro para as características químicas. Frutos "mistos" assemelhamse aos frutos consumidos exclusivamente por aves em relação aos padrões de variação das características morfológicas e químicas, o que sugere serem eles frutos primariamente ornitocóricos que são também explorados por mamíferos. Frutos "mistos" são comuns em florestas tropicais e representam excelente oportunidade para contrastar a efetividade de diferentes grupos funcionais de frugívoros ao dispersar a mesma espécie de planta. Palavras-chave: dispersão de sementes, frugívoros, síndromes de dispersão, composição química de frutos. 


\section{Introduction}

The diversity of fleshy fruits in tropical rain forests is astonishing, and has called the attention of naturalists and modern ecologists for a long time. In fact, the proportion of species with fleshy fruits dispersed by vertebrates can reach up to $90 \%$ in some tropical plant communities (Jordano 2000, Almeida-Neto et al. 2008).

Fleshy fruit traits (color, morphology and chemistry) are thought to be an adaptation to their major seed dispersers or to major seed predators, such as pathogens (Herrera 1982, van der Pijl 1982, Cipollini and Levey 1997, Cazetta et al. 2008). During the last decades, numerous studies on seed dispersal systems analyzed the fruit morphology and chemical characteristics, but most of these studies were species-oriented, and few took the entire community into consideration (e.g. Stiles 1980, Johnson et al. 1985, Debussche et al. 1987, Herrera 1987, Eriksson \& Ehrlén 1991, Corlett 1996, Gautier-Hion et al. 1985, Kitamura et al. 2002). Community-wide studies of fruit attributes (including morphology and chemical traits) have been conducted in some temperate ecosystems (Herrera 1987, Johnson et al. 1985, Snow \& Snow 1988, Traveset et al. 2004), but few have been undertaken in tropical species-rich communities (Wheelwright et al. 1984).

The Atlantic Forest was once the longest rain forest in the world (spanning between $4^{\circ}$ to $32^{\circ} \mathrm{S}$ ), ranging from the North of Brazil up to Paraguay and Argentina. Estimates of remaining Atlantic forest in Brazil ranged from $11.4 \%$ to $16 \%$ (Ribeiro et al. 2009). As a consequence of widespread and ongoing degradation on remaining forest tracts, most plant communities are dominated by edge species with clear impoverishment and changes in functional diversity (Girão et al. 2007). Therefore, opportunities to study the functional diversity, here defined as the number of distinct functional groups or types identified by shared suites of traits or ecological strategies (Hooper \& Vitousek 1997), in undisturbed Atlantic Forest sites are vanishing. Such studies, however, are essential to understand how this diversity may change due to environmental changes.

In this paper we describe the diversity of fruit functional traits, such as fruit and seed size, mass, color and chemical composition of pulp or aril of vertebrate-dispersed fruits in a pristine lowland Atlantic rainforest in Southeast Brazil. We are particularly interested in understanding how these fruit functional traits are related to distinct seed dispersal groups, especially birds and mammals, the two most frequent groups of seed dispersers at the study site. It has been documented that, together with fruit size, succulence (variation across species in sugar and water content of the pulp and energy content, e.g., lipids) are major elements of the biodiversity of fleshy fruits at the community level (Herrera 1987, Snow \& Snow 1988, Jordano 2000). However, no study has simultaneously considered fruit morphology, pulp nutrient content and color in species-rich tropical communities. Here, we expect to fulfil this gap with the first study conducted in the Brazilian Atlantic Forest that analyze a suite of functional traits of fleshy fruits with a community-wide perspective.

\section{Material and Methods}

\section{Study site}

The present study was carried out in a lowland Atlantic rain forest at the Saibadela research station of the Parque Estadual Intervales, Sete Barras, SP, Southeast Brazil (24 $14^{\prime}$ S and 48 04' W; 60-120 m a.s.1.), mainly from 1994 to 1997, and from 1999 to 2002 . Intervales Park is a protected area with $490 \mathrm{~km}^{2}$, comprising with adjacent reserves one of the largest blocks of Atlantic forest remaining in Brazil. In the Saibadela forest there is no marked seasonal distribution of rainfall, but we can divide the year into two main seasons: the wettest season from October to March ( $>75 \%$ of annual rainfall), and a less wet or driest season from April to September. Mean annual rainfall is around $4,000 \mathrm{~mm}$, and annual mean temperature is $22{ }^{\circ} \mathrm{C}$ (Guilherme et al. 2004).

Old-growth forest (sensu Clark 1996) predominates at the study site; the understory is open and the canopy can reach 25-30 m height. A total of 436 angiosperm plant species (233 genera, 90 families) have been collected at the study site so far (Zipparro et al. 2005). The forest tree structure and composition in the Saibadela forest was investigated concomitantly with this study by Almeida-Scabbia (1996), and in a more extensive investigation conducted by Guilherme et al. (2004). Eight species-rich families accounted for $45 \%$ of the total species sampled: Myrtaceae (55 species), Rubiaceae (32), Fabaceae (25), Melastomataceae (23), Araceae (20) and Lauraceae, Orchidaceae and Solanaceae (14 species each) (Zipparro et al. 2005). Guilherme et al. (2004) found a density of 1554 plants/ha with $\geq 5 \mathrm{~cm}$ diameter at breast height (dbh). Families with the highest number of individuals were Myrtaceae $(24.2 \%)$, Arecaceae $(22.1 \%)$ and Rubiaceae $(10.0 \%)(\mathrm{n}=804)$. The families with the highest basal areas were Myrtaceae, Elaeocarpaceae, Euphorbiaceae, Fabaceae, Arecaceae and Rubiaceae (Guilherme et al. 2004).

A complete suite of vertebrate seed dispersers may be found at the study site (Galetti 1996, Aleixo \& Galetti 1997, Vieira \& Izar 1999, Pizo 2002). These include large frugivorous birds (e.g., toucans and guans; Galetti et al. 1997, 2000), monkeys (e.g., woolly spider monkeys Brachyteles arachnoides (É. Geoffroy, 1806); Izar 1999), and terrestrial mammals (e.g., agoutis Dasyprocta leporine L., tapirs Tapirus terrestris (Linnaeus, 1758) (Rodrigues et al. 1993). The fruit-frugivore relationship has been intensively studied in the area (Galetti 1996, Vieira \& Izar 1999, Pizo 2002).

\section{Fruit morphology and chemical analysis}

In this paper, the botanical term "fruit" was used in a broad sense to describe all kinds of diaspores irrespective of their origin and structure (i.e., "true" fruit, pseudo-fruit, aril plus seed, synconium, etc.). The fruit species eaten by frugivorous vertebrates were classified according to growth form (tree, shrub, herb, liana, epiphyte or hemiepiphyte), color of the ripe fruit, number of seeds per fruit, and type of fruit display (bicolored or not). Based on previous definitions (Willson \& Thompson 1982), we distinguished morphologically bicolored fruits (i.e., when ripe fruit color contrasts with the color of some accessory structure) and temporally bicolored fruits (i.e., when the contrast involves ripe and unripe fruits). We assigned ripe fruits of each species based on human perception to one of nine color categories commonly used by other researches (see Wheelwright \& Janson 1985): black (including dark red), red (including pink), yellow, orange, brown, gray, green, white and blue (including purple). The length and width (diameter) of 10-15 fruits and seeds of each species were measured with a calliper. Fruit and seed masses were estimated using Pesola ${ }^{\circledR}$ spring scales.

A seed disperser group (bird, monkey, bat, marsupial, ungulate or rodent) was assigned to each fruit species based on field observations (Galetti 1996, Izar 1999, Vieira \& Izar 1999, Pizo 2002) and from information provided by other researchers working in the area. The ungulate-rodent guild was composed by the tapir and agouti. When birds and any mammal group (mainly monkeys in our case) were observed eating the seeds of the same fruit species, we used the category mixed. Seed predators (small rodents and psittacids) were not included in this analysis.

Major chemical constituents (water, proteins, carbohydrates, lipids and ash) were analyzed from the pulps and arils of recently collected fruits. Seeds were not included in the analysis, except for 
Cecropia pachystachya Trécul, Marcgravia polyantha Delpino, Ficus spp., Sorocea bonplandii (Baill.) W.C. Burger, Lanj. \& Wess. Boer, Phytolacca dioica L. and Coussarea contracta (Walp.) Müll. Arg. which, however, were not included in protein analysis. At least $20 \mathrm{~g}$ (fresh mass) of each fruit species was used for analyses, an amount that often required the sampling of more than one individual tree. Lipids were analyzed according to the method described by Bligh \& Dyer (1959). Total nitrogen (N) was analyzed by the micro-Kjeldahl method, and converted into crude protein by multiplying $\mathrm{N}$ by 6.25 (AOAC, 1990). Ash proportion was determined by incinerating the samples in a muffle furnace set at $550{ }^{\circ} \mathrm{C}$ until the weight stabilized. Total carbohydrates were estimated by difference.

\section{Data analyses}

Pearson's correlations were used to analyze the relationships among fruit traits. For this, morphological variables were log-transformed and the proportions of fruit chemical constituents were arcsine-transformed. To test for differences in morphology and chemistry between fruits exclusively eaten by birds and those eaten exclusively by mammals (mainly monkeys), median tests (applied for seed number, seed width and length, seed and fruit masses) and $t$ tests (for all other variables) were used with Bonferroni-corrected $\mathrm{P}$ levels. It should be noted, however, that the statistical significance of these tests may be inflated because of the lack of phylogenetic independence among species (Felsenstein 1985).

Chi-square goodness of fit test was used to examine the distribution of fruit colors among fruit species eaten by birds and mammals (including mixed). Observed frequencies were compared with those expected if both disperser groups choose fruits randomly in respect to color; expected frequencies were obtained from the frequencies of fruit species of different colors sampled. The same rationale was used to investigate the distribution of mixed and bicolored fruits among plant habits. Two Principal Component Analyses (PCA) were performed on the matrix of plant species $\times$ fruit traits, one with morphological variables and other with the chemical components analyzed. Using the varimax rotation method, we extracted from the PCA the factors with eigenvalues $\geq 1.0$. Analyses were performed using Statistica v. 6.0 (Statsoft 1996).

\section{Results}

\section{Fruit morphology and color}

Fruits of 186 plant species representing 57 families (133 trees, 17 shrubs, 11 hemi-epiphytes, 11 lianas, 8 herbs, and 6 epiphytes) were measured (Appendix 1). Although we obtained color information for all the fruit species sampled, data on the seven morphological variables were not available for every species. Data on seed number were available for $74 \%$, on fruit dimensions for $66 \%$, on seed dimensions and fruit and seed masses for $65 \%$ of the species sampled. The species sampled represent approximately $43 \%$ of the presently known angiosperm flora of the Saibadela forest, being responsible for about $75 \%$ of total basal area estimated for plants with $\mathrm{dbh} \geq 5 \mathrm{~cm}$ (Guilherme et al. 2004). The most common families sampled were Myrtaceae (11 genera, 37 species), Rubiaceae (9 genera, 14 species), Melastomataceae (5 genera and 9 species), and Araceae (4 genera, 9 species), which are among the most speciose families at Saibadela (Appendix 1; Zipparro et al. 2005).

Birds and monkeys were the most frequent seed dispersers, being assigned as the main frugivores to 145 and 76 fruit species, respectively (Appendix 1). Other dispersers were rodents (seven fruit species), bats and marsupials (six species each), and ungulates (two species). For five fruit species no disperser group was recorded
(Appendix 1). Fifty fruit species have been categorized as having a mixed seed dispersal system. Mixed fruits do not occur among shrubs and herbs, i.e. in the lower strata of the forest, being far more common among hemi-epiphytes than expected by chance $\left(\chi^{2}=21.30, \mathrm{df}=5\right.$, $\mathrm{p}<0.001)$. This result is largely due to the family Araceae, which is relatively rich in species in the Saibadela forest (ca. 20 species recorded to date; Zipparro et al. 2005).

About $55 \%$ of species sampled have only one or two seeds/fruit (Figure 1a; Appendix 1). Likewise, fruit and seed sizes are highly skewed to the right (Figure 1b, c). Fruit and seed mass varied in two orders of magnitude (Table 1). With the exception of the number of seeds and traits related to fruit size (width, length, and mass), all other pairwise correlations involving morphological traits were significant (Table 2). Fruits eaten exclusively by birds differed in all morphological traits but seed number from those eaten solely by
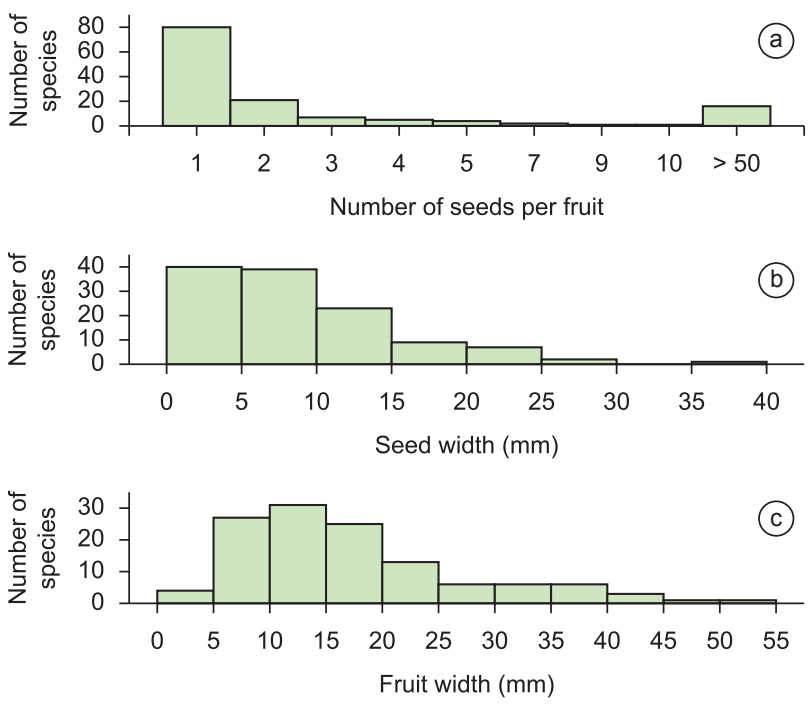

Figure 1. Frequency distributions of a) number of seeds per fruit; b) seed width; and c) fruit width among the vertebrate-dispersed fruits of the Saibadela forest. Fruit and seed widths were positively correlated to all morphological parameters related to fruit and seed sizes (i.e., length and mass; see Table 2).

Table 1. Summary statistics for the morphological and chemical traits of vertebrate-dispersed fruits of the Saibadela forest. Because seed number and the width and length of multi-seeded, small fruits were not precisely measured, means and standard deviations are not presented for these traits. Values for chemical traits are proportions relative to dry mass.

\begin{tabular}{|c|c|c|c|c|c|}
\hline & Mean & Median & SD & Range & $\mathbf{N}$ \\
\hline \multicolumn{6}{|l|}{ Morphological } \\
\hline No. seeds/fruit & - & 1.0 & - & $1->50$ & 137 \\
\hline Seed width (mm) & - & 7.0 & - & $<1-35.0$ & 121 \\
\hline Seed length (mm) & - & 11.0 & - & $<1-67.0$ & 121 \\
\hline Fruit width (mm) & 16.7 & 14.0 & 10.1 & $4.0-50.0$ & 123 \\
\hline Fruit length (mm) & 19.9 & 16.0 & 14.1 & $4.0-101.0$ & 123 \\
\hline Seed mass (g) & - & 0.3 & - & $<0.1-29.0$ & 121 \\
\hline Fruit mass (g) & - & 2.0 & - & $<0.1-72.7$ & 121 \\
\hline \multicolumn{6}{|l|}{ Chemical } \\
\hline Water & 0.79 & 0.81 & 0.11 & $0.43-0.94$ & 63 \\
\hline Lipids & 0.12 & 0.05 & 0.19 & $0.01-0.89$ & 64 \\
\hline Proteins & 0.08 & 0.08 & 0.03 & $0.03-0.19$ & 56 \\
\hline Carbohydrates $^{\mathrm{a}}$ & 0.75 & 0.81 & 0.19 & $0.05-0.92$ & 59 \\
\hline Ash & 0.04 & 0.04 & 0.03 & $0.01-0.20$ & 59 \\
\hline
\end{tabular}

aTotal carbohydrates. 
mammals. Overall, bird-dispersed fruits and their seeds are smaller than mammal-dispersed fruits and seeds, with mixed fruits in between but closer to the bird group (Table 3).

The first two factors of the PCA conducted with the fruit morphological traits accounted for $79.2 \%$ of total variation. The first factor is mostly related to fruit size, with fruit width, fruit length, and fruit mass having large positive loadings on it (Table 4). This axis separates the mammal-dispersed species from species that are either bird-dispersed or have a mixed seed dispersal system (Figure 2a). The second factor is heavily influenced by seed traits: seed number influenced it positively whereas traits related to seed size (seed length and width) have negative loadings. The second axis separates fruit species with many tiny seeds eaten either by birds (e.g., Clidemia blepharodes DC., Melastomataceae), mammals (e.g., Jacaratia spinosa (Aubl.) A. DC., Caricaceae) or with a mixed dispersal system (e.g., Ficus spp., Moraceae) from the others.

Table 2. Pearson correlations among the morphological and chemical traits of vertebrate-dispersed fruits of the Saibadela forest. Values with an asterisk are significant $(\mathrm{p}<0.001)$.

\begin{tabular}{|c|c|c|c|c|c|c|}
\hline & $\begin{array}{c}\text { No. seeds/ } \\
\text { fruit }\end{array}$ & $\begin{array}{c}\text { Seed } \\
\text { width }\end{array}$ & $\begin{array}{c}\text { Seed } \\
\text { length }\end{array}$ & $\begin{array}{l}\text { Fruit } \\
\text { width }\end{array}$ & $\begin{array}{c}\text { Fruit } \\
\text { length }\end{array}$ & $\begin{array}{l}\text { Seed } \\
\text { mass }\end{array}$ \\
\hline Morphological & - & - & - & - & - & - \\
\hline No. seeds/fruit & - & - & - & - & - & - \\
\hline Seed width & $-0.67 *$ & - & - & - & - & - \\
\hline Seed length & $-0.70 *$ & $0.95^{*}$ & - & - & - & - \\
\hline Fruit width & 0.05 & $0.54 *$ & $0.43 *$ & - & - & - \\
\hline Fruit length & 0.12 & $0.46^{*}$ & $0.44 *$ & $0.83^{*}$ & - & - \\
\hline Seed mass & $-0.44 *$ & $0.80^{*}$ & $0.75^{*}$ & $0.66^{*}$ & $0.60 *$ & - \\
\hline \multirow[t]{2}{*}{ Fruit mass } & 0.06 & $0.53 *$ & $0.45^{*}$ & $0.91 *$ & $0.88 *$ & $0.69^{*}$ \\
\hline & Water & Lipids & Prot. & Carb. & & \\
\hline \multicolumn{7}{|l|}{ Chemical } \\
\hline Water & - & - & - & - & - & - \\
\hline Lipids & $-0.59 *$ & - & - & - & - & - \\
\hline Proteins & 0.11 & 0.03 & - & - & - & - \\
\hline Carb. $^{a}$ & $0.54 *$ & $-0.97 *$ & -0.20 & - & - & - \\
\hline Ash & $0.43 *$ & $-0.37 *$ & 0.11 & 0.24 & - & - \\
\hline
\end{tabular}

${ }^{a}$ Total carbohydrate
Most of the fruits were black, red or yellow when ripe. Other colors were orange, green, white, blue, brown and gray (Figure 3). Blue, a relatively rare color among fleshy fruits, is particularly common in understory herbs and shrubs of the family Rubiaceae (Psychotria spp., Coccocypselum sp.). Thirty-one species (17.0\%) produced morphologically bicolored fruits, while only five species $(2.7 \%)$ bear temporally bicolored fruits (Appendix 1). Once again the latter were more common among the Rubiaceae. Despite being present in all strata of the forest, bicolored fruits are not randomly distributed among plant habits $\left(\chi^{2}=14.71, \mathrm{df}=5, \mathrm{P}=0.01\right)$, being overrepresented among herbs (six out of eight species) and epiphytes (three out of five species) (Appendix 1). A variety of accessory structures are involved in morphologically bicolored displays, but the most common combinations are given by colorful arils (usually white or red) contrasting either with the outer (yellow or red) or inner (usually white) surfaces of fruit capsules $(38.7 \%$ ) or with black seeds (29.0\%). In only three species (Aechmea nudicaulis (L.) Griseb. Bromeliaceae, Stromanthe sanguinea Sond. - Marantaceae, and Clidemia blepharodes - Melastomataceae) more than two structures are combined to produce the bicolored display (Appendix 1).

Black, red and morphologically bicolored fruits predominate among bird fruits (Figure 3), although birds do not explore any fruit color more often than expected by chance $\left(\chi^{2}=15.76, \mathrm{df}=9\right.$, $\mathrm{P}=0.07)$. Mammals, on the contrary, do not explore fruits irrespective of fruit color $\left(\chi^{2}=22.18, \mathrm{df}=9, \mathrm{P}=0.008\right)$, mainly due to their positive association with yellow and green fruits, and the low frequency of bicolored displays among mammal fruits (Figure 3). Fruits in the category mixed are not significantly associated with any color in particular $\left(\chi^{2}=6.70, \mathrm{df}=9, \mathrm{P}=0.67\right)$; all the colors considered in this study except gray occur in mixed fruits.

\section{Fruit chemistry}

For 64 species (43 genera, 27 families) the proportions of water, lipids, protein, total carbohydrate, and ash were determined (Appendix 2). Summary statistics and frequency distributions for the fruit chemical constituents analyzed are presented in Table 1 and Figure 4, respectively. Water and carbohydrates showed leftskewed distributions, whereas lipids and proteins were right-skewed

Table 3. Summary statistics for morphological and chemical traits of fleshy fruits eaten by birds, mammals, and both (mixed) in the Saibadela forest. Values for seed number, seed width, seed length, seed mass, and fruit mass are medians; all others are mean values \pm SD. Chemical contents are expressed in proportions of freshy (water) or dry mass (all others) of pulp. Sample sizes (i.e., number of species) are indicated in parentheses.

\begin{tabular}{lcccc}
\hline \multicolumn{1}{c}{ Traits } & Birds & Mixed & Mammals & Birds $\times$ Mammals, Pa \\
\hline Morphological & & & & \\
\hline No. seeds/fruit & $1.0(59)$ & $1.0(43)$ & $1.5(30)$ & 0.27 \\
Seed width (mm) & $6.0(53)$ & $6.0(39)$ & $11.5(24)$ & $<0.001$ \\
Seed length (mm) & $8.0(53)$ & $9.0(39)$ & $16.5(24)$ & $<0.001$ \\
Fruit width (mm) & $11.3 \pm 5.1(50)$ & $14.3 \pm 6.9(41)$ & $28.9 \pm 10.08(27)$ & $<0.001$ \\
Fruit length (mm) & $13.1 \pm 5.4(50)$ & $16.4 \pm 6.9(40)$ & $36.1 \pm 19.5(28)$ & $<0.001$ \\
Seed mass (g) & $0.2(53)$ & $0.2(43)$ & $13.3(28)$ & $<0.001$ \\
Fruit mass (g) & $0.8(47)$ & $1.7(41)$ & & $<0.001$ \\
\hline Chemical & & & & $0.82 \pm 0.06(13)$ \\
Water & $0.79 \pm 0.14(22)$ & $0.77 \pm 0.10(27)$ & $0.05 \pm 0.03(13)$ & 0.69 \\
Lipid & $0.15 \pm 0.22(23)$ & $0.14 \pm 0.21(27)$ & $0.07 \pm 0.03(13)$ & 0.34 \\
Protein & $0.09 \pm 0.04(22)$ & $0.09 \pm 0.03(20)$ & $0.83 \pm 0.06(13)$ & 0.12 \\
Total carbohydrates & $0.72 \pm 0.23(21)$ & $0.73 \pm 0.19(24)$ & $0.05 \pm 0.04(13)$ & 0.32 \\
Ash & $0.04 \pm 0.02(21)$ & $0.05 \pm 0.02(24)$ & \\
\hline
\end{tabular}

${ }^{\text {a}}$ Student's $t$-tests applied on log-transformed data for fruit width and length, and arcsine-transformed data for chemical traits. Median tests applied to ${ }^{\circ}$. seeds/fruit, seed width, seed length, seed mass, and fruit mass; Bonferroni-corrected $p$ level $=0.007$ and 0.01 for tests involving morphological and chemical traits, respectively. 
(Figure 4). Water and carbohydrates predominate in the pulp of fruits. Lipids are the most variable component (Appendix 2). Water content was positively correlated with carbohydrates. Lipids correlated negatively with water and carbohydrates. Ash content was positively correlated with water and negatively correlated with lipids (Table 2). Unlike morphology, fruits eaten by birds did not differ from mammal fruits in any of the chemical traits analyzed (Table 3 ).

The PCA analysis conducted with fruit chemical traits revealed that two factors accounted for $75.8 \%$ of total variation. The first factor reflects a gradient in fruit succulence; species with watery fruits, rich in carbohydrates have positive loadings on it whereas species with oily fruits scored negatively (Table 4; Figure 2b). The second factor is dictated by ash and, especially, protein content, which scored positively on it (Table 4). Superimposing the seed disperser categories on the PCA plane we note that mammal-dispersed fruits tend to be less chemically variable than fruits with a mixed seed dispersal system and fruits dispersed exclusively by birds (Figure 2b; compare also the standard deviations in Table 3).
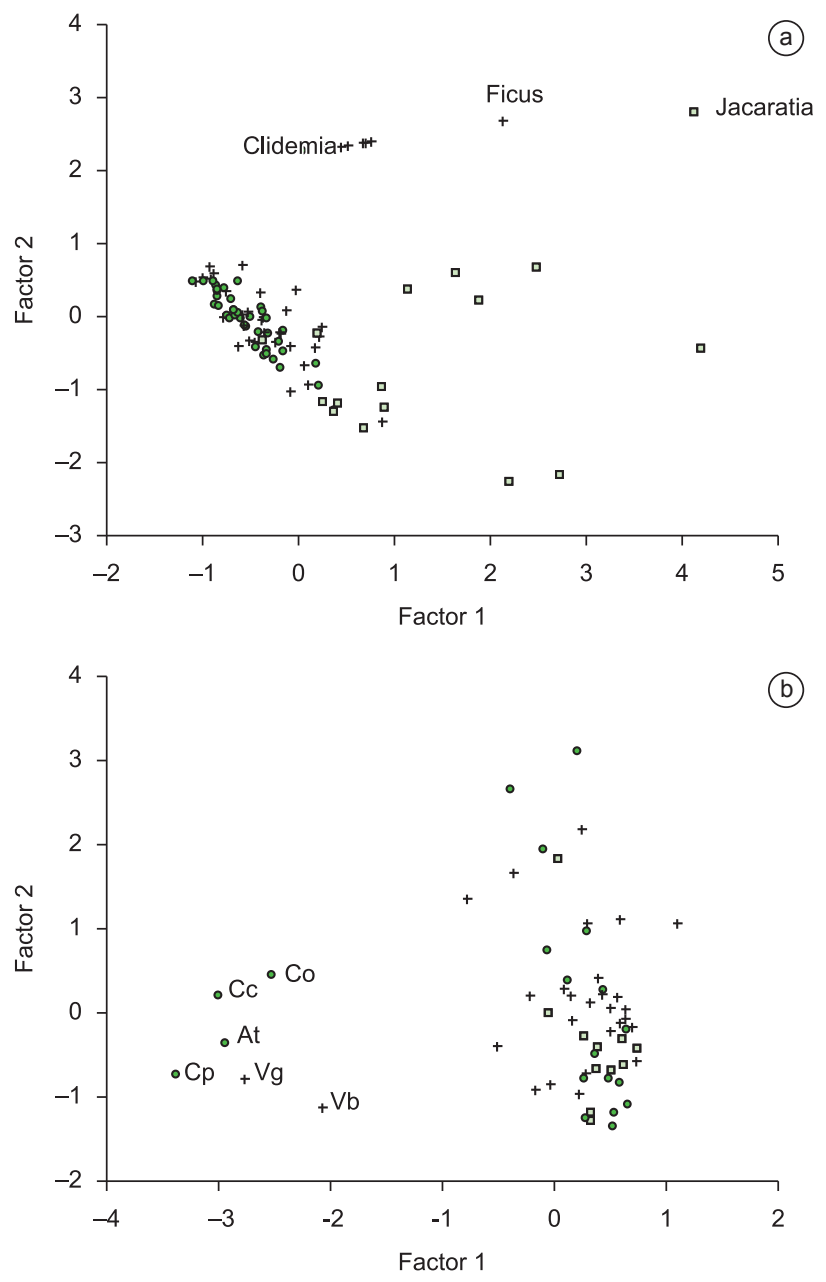

Figure 2. Locations of fleshy-fruited plant species of the Saibadela forest on the first two principal component axes of a) morphological; and b) chemical fruit traits. Species were categorized according to their seed dispersers: mammals (squares), birds (circles), and mixed (monkeys plus birds; crosses). In a) the species cited in the text and highlighted in the graph are Clidemia blepharodes, Ficus gomelleira, and Jacaratia spinosa. In b) the lipidrich species shown are: $\mathrm{Co}=$ Cupania oblongifolia, $\mathrm{Cc}=$ Cabralea canjerana, $\mathrm{At}=$ Alchornea triplinervia, $\mathrm{Vg}=$ Virola gardneriana, $\mathrm{Vb}=$ Virola bicuhyba, $\mathrm{Cp}=$ Clusia parviflora .

\section{Discussion}

\section{Community patterns in fruit morphology and color}

This study revealed many similar trends and subtle differences with other studies (Knight \& Siegfried 1983, Wheelwright \& Janson 1985, Herrera 1987, Dowsett-Lemaire 1988, Willson et al. 1989, Corlett 1996, Nakanishi 1996). As reported for other floras (Herrera 1987, Corlett 1996), the frequency distributions of seed number, fruit and seed sizes are highly skewed to the right. Similarly, the fruit color spectrum found at Saibadela parallels those found in other communities, with black and red being the most common colors (Knight \& Siegfried 1983, Willson et al. 1989, Corlett 1996). The predominance of black over red in bird fruits seems to be a characteristic feature of most plant communities (Wheelwright \& Janson 1985, Knight \& Siegfried 1983, Nakanishi 1996), but it is different from savanna communities (Donatti et al. 2007). Worth mentioning is the greater proportion of green color among bird fruits in Saibadela when compared to other tropical (Wheelwright \& Janson 1985), subtropical (Long 1971), and temperate communities (Nakanishi 1996) (7.1\% vs. 0-4.8\%). This difference is greatly due to the contribution of families Moraceae, Cecropiaceae, and Araceae, the latter being especially speciose at Saibadela (Zipparro et al. 2005).

The overall proportion of bicolored fruits (ca. 20\%) is similar to that found for Queensland rainforest trees in Australia (23\%; Willson et al. 1989). As in Australia, bicolored fruits are associated with dispersal by birds in Saibadela. Considering only bird-dispersed fruits, the percentage of bicolored fruits in Saibadela (24\%) fall in between temperate communities in Japan (16\%; Nakanishi 1996) and North America (ca. 32\%; Willson \& Thompson 1982) but, in contrast with these communities, bicolored fruits are common among herbs in the Saibadela forest, especially in the families Commelinaceae and Heliconiaceae (Appendix 1).

In relation to fruit morphology, our results basically follow the patterns observed in other localities (Janson 1983, Knight \& Siegfried 1983, Gautier-Hion et al. 1985), for the angiosperm clade in general (Jordano 1995), and in a large-scale study conducted at the Atlantic forest (Almeida-Neto et al. 2008). Bird fruits tend to be smaller than

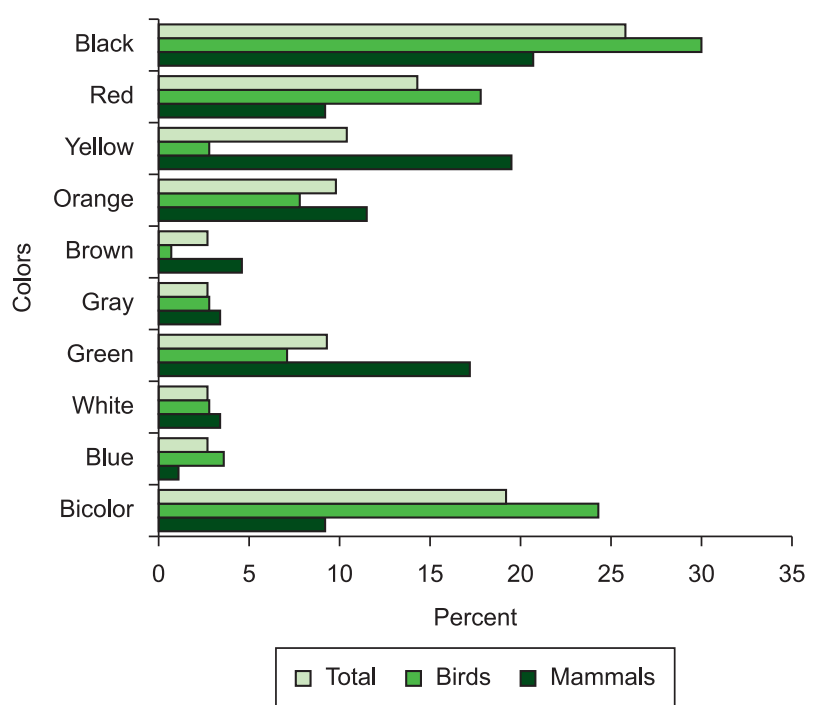

Figure 3. Frequencies of ripe fruit colors of vertebrated-dispersed plant species according to their seed dispersers, either birds ( $n=145$ species $)$ or mammals $(n=87)$, in the Saibadela forest. Total refer to the entire plant community $(n=186)$, irrespective of seed disperser. 
mammal fruits, being colored black or red, whereas mammal fruits are often yellow or green, a distinction that corroborate the frequent finding that size and color are fruit features that evolutionarily respond to different dispersal agents (Jordano 1995, Pizo 2002, Lomáscolo \& Schaefer 2010). Bird fruits are more conservative in morphology than mammal fruits, which is not surprising given the variety of trophic structures and handling abilities among mammalian seed dispersers. That mixed fruits are closer to bird fruits in what concerns fruit morphology likely reflects such wider handling abilities of mammals, especially primates, that are able to consume fruits primarily adapted to bird dispersal. The exploitation of primarily bird-dispersed fruits by mammals, however, may not be neutral, but occur at the expenses of the efficiency of seed dispersal. For instance, the seed deposition patterns produced by birds and monkeys are likely different; while birds often regurgitate isolated seeds, especially medium- or largesized seeds, monkeys defecate them in groups. With two Myrtaceae species occurring at Saibadela (Gomidesia anacardiaefolia (Gardner) O. Berg and Marlierea obscura O. Berg), Pizo (2003) experimentally shown that the deposition of isolated seeds provided a better balance between number of dispersed seeds and number of established seedlings, suggesting that, in comparison with monkeys, birds may optimize the reproductive effort of both plant species. Therefore, although birds and mammals exploit the fruits of the same plant species, their evolutionary effects upon plant populations may not be the same.

\section{Community-wide patterns of chemical content}

Similarly to fruit morphology, our results for fruit chemical composition reflect general patterns observed for fleshy fruits as, for example, the left skewness for water and carbohydrates, the right

Table 4. Pattern of rotated factors (factor loadings, extracted by principal components) for separate analyses of fruit morphological and chemical traits of vertebrate-dispersed fruits of the Saibadela forest. Varimax rotation method was used. Loadings that strongly affect each factor $(>0.60)$ are in boldface.

\begin{tabular}{lrrlrr}
\hline \multicolumn{1}{c}{ Morphology } & PC 1 & PC 2 & Chemical & PC 1 & PC 2 \\
\hline No. of seeds/fruit & 0.37 & $\mathbf{0 . 7 9}$ & Water & $\mathbf{0 . 8 3}$ & 0.18 \\
Seed width & 0.46 & $\mathbf{- 0 . 8 3}$ & Lipids & $\mathbf{- 0 . 9 6}$ & -0.08 \\
Seed length & 0.40 & $\mathbf{- 0 . 8 3}$ & Protein & -0.09 & $\mathbf{0 . 9 1}$ \\
Fruit width & $\mathbf{0 . 8 8}$ & -0.34 & Carb. $^{\mathrm{a}}$ & $\mathbf{0 . 9 5}$ & -0.13 \\
Fruit length & $\mathbf{0 . 8 7}$ & -0.13 & Ash & 0.42 & 0.46 \\
Seed mass & 0.41 & -0.59 & - & - & - \\
Fruit mass & $\mathbf{0 . 9 0}$ & -0.10 & - & - & - \\
Eigenvalue & 3.97 & 1.57 & - & 2.72 & 1.07 \\
Cumulative \% variance & 56.7 & 79.2 & - & 54.5 & 75.9 \\
\hline
\end{tabular}

aTotal carbohydrates. skewness for lipids and proteins, the complementary trends between carbohydrates (and to a lesser extent water) and lipids (Herrera 1987, Jordano 1995, Corlett 1996), and the great interspecific variability in lipid content (Corlett 1996, Jordano 2000, but see Herrera 1987). This community-wide pattern of fruit traits is paralleled and influenced by within-family profiles as, for example, what is observed for Myrtaceae (Pizo 2002), a dominant family at the Saibadela forest.

For sake of comparison, we used the fruit database (FRUBASE) of Jordano (1995) and averaged the major chemical components of fruits across six phytogeographic regions (Table 5). We noted that fruits in the Saibadela forest did not differ greatly from fruits sampled in other Neotropical communities. What is evident is that fruits in the Neotropics, along with Australasian fruits, have greater lipid content than African fruits and fruits taken from temperate regions of Europe and North America. Historical aspects must be considered as an underlying cause for these differences, because plant families that typically produce lipid-rich fruits (e.g., Lauraceae, Meliaceae, Myristicaceae) are found mainly in tropical forests (Herrera 1981, Snow 1981). Apart from these idiosyncrasies, the great question is what drives the general trend of similarity among the Saibadela and these distinct floras? Perhaps it is the fact that the Saibadela forest assembles an extraordinary diversity of fleshy fruited species, and this reproduces the general, worldwide pattern because it combines higher taxa with distinct fruit types and pulp constitutions. It can also be that the major higher taxa that compose the Saibadela community (e.g., Myrtaceae, Rubiaceae) are less conservative in fruit traits and show the general trends of fruit traits among their component species.

Fruit lipids and secondary compounds are good predictors of fruit removal (Cazetta et al. 2008), what gives room for frugivores exert evolutionary pressure upon these traits, but variation across species in fruit chemistry is also determined to a large extent by common ancestry (Jordano 1995). Stiles (1993), for example, found that captive birds prefer lipid-rich fruits (but see Johnson et al. 1985, Borowicz 1988), whereas mammals tend to avoid them (Debussche \& Eisenmann 1989, Herrera 1989). Mammal fruits at Saibadela are more chemically homogeneous than bird fruits, which relates to the fact that birds eat fruits with a wide range of lipid content, while mammals concentrate on lipid-poor fruits. In what concerns fruit chemistry, mixed fruits resemble bird fruits in also being widespread in the PCA plan derived from the fruit major chemical constituents.

In summary, we noted that the morphological and chemical traits of fruits of the Saibadela forest generally resemble the patterns observed in fleshy fruits worldwide. We know that traits related to fruit morphology and chemical composition are correlated to plant phylogeny (Jordano 1995) and, as a consequence, taxonomic composition of fruiting plants at different sites influences the patterns of variation in fruit morphology (Herrera 2002). The similarities

Table 5. Mean proportions for the major chemical components analyzed from the pulps of fleshy fruits sampled in the Saibadela forest and at each of the major regions included in Jordano's (1995) database. Number of species analyzed is given in parentheses. Proportions of water are reported on a fresh mass basis; other components based on dry mass of fruit pulp.

\begin{tabular}{|c|c|c|c|c|c|}
\hline Area $^{a}$ & Water & Lipid & Protein & $\mathrm{NSC}^{{ }^{b}}$ & Ash \\
\hline Africa & $0.70(67)$ & 0.09 (119) & $0.06(123)$ & $0.59(118)$ & $0.04(82)$ \\
\hline Australasia & $0.76(73)$ & $0.15(75)$ & $0.07(85)$ & $0.54(25)$ & $0.08(5)$ \\
\hline Mediterranean Europe & $0.62(86)$ & $0.08(76)$ & $0.05(76)$ & $0.68(73)$ & $0.05(73)$ \\
\hline North Europe & $0.73(45)$ & $0.04(35)$ & $0.04(34)$ & $0.46(34)$ & $0.05(15)$ \\
\hline North America & $0.81(53)$ & $0.06(50)$ & $0.06(76)$ & $0.59(51)$ & $0.05(30)$ \\
\hline Neotropical & $0.74(182)$ & $0.15(137)$ & $0.06(164)$ & $0.49(155)$ & $0.06(57)$ \\
\hline Saibadela forest & $0.79(63)$ & $0.12(64)$ & $0.08(56)$ & - & $0.04(59)$ \\
\hline
\end{tabular}

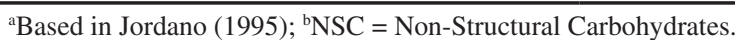



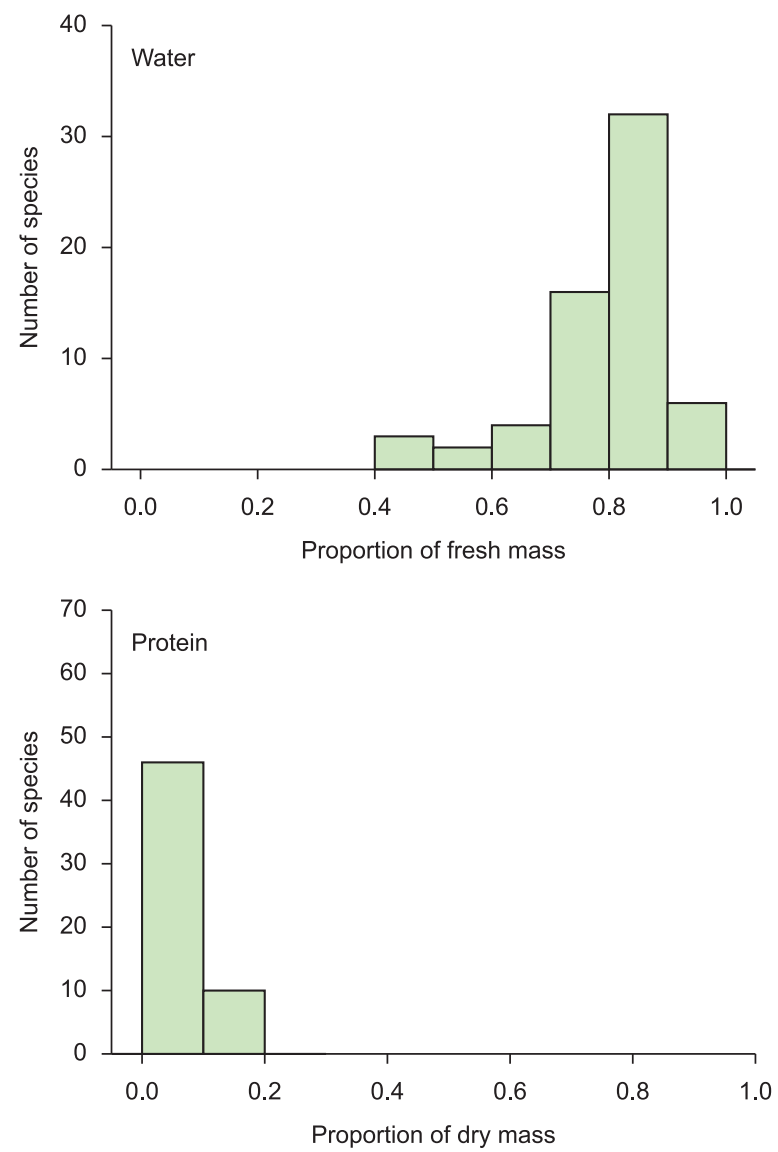
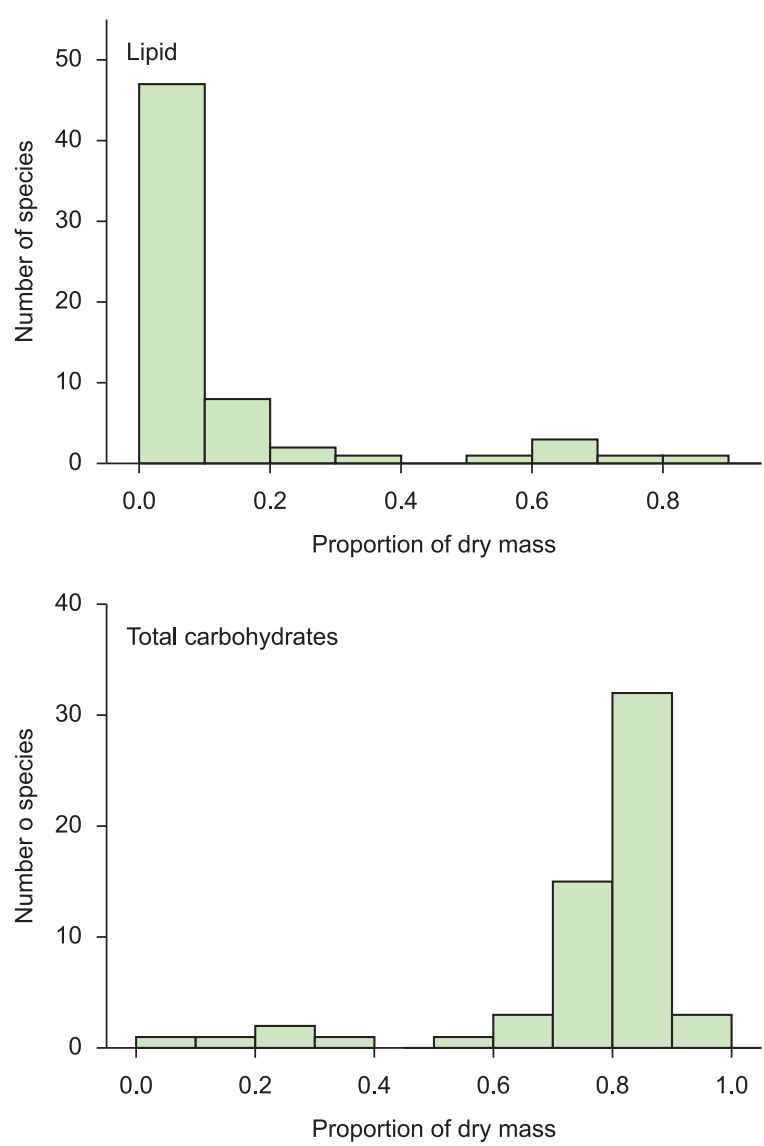

Figure 4. Frequency distributions of contents of water and the major chemical components of vertebrate-dispersed fruits collected in the Saibadela forest.

highlighted here involving the Saibadela forest and a diverse array of floras point to general patterns of worldwide validity, either determined by homogeneous, worldwide evolutionary influence of seed dispersers and/or pervasive plant physiology/fruit development constraints.

The distinction we made among bird, mammal and mixed fruits revealed that mammal fruits are more variable than bird fruits in relation to morphological traits, while the reverse is true for chemical traits. Mixed fruits resemble bird fruits in the patterns of variation of morphological and chemical traits, suggesting that they are primarily bird-dispersed fruits that are also exploited by mammals. Such fruits are common in tropical forests (e.g. at Barro Colorado Island in Panamá, 85 of 89 of the animal-dispersed plant species had dispersal agents from two of three animal-dispersed categories, either bats, nonvolant mammals or birds; Muller-Landau et al. 2008), where they present excellent opportunities to contrast the effectiveness of different functional groups of frugivores dispersing the same plant species. A recent study with Solanum granuloso-leprosum Dunal (Solanaceae), a pioneer, small-seeded tree of open areas and forest edges dispersed by birds and bats, illustrates this point. While bats removed more fruits than birds, performing better in the quantitative component, birds improved the germination performance of seeds, an aspect of the qualitative component of seed dispersal effectiveness (Jacomassa \& Pizo 2010). This example shows that in the mixed dispersal category, different dispersal groups might not weigh equally in respect to their effectiveness of seed dispersal, which may translate to their effects upon population recruitment.

\section{Acknowledgements}

We would like to thank Pedro Jordano for valuable suggestions on the manuscript. FAPESP (Project Biota 2001/14463-5 and 2001/10300-4; Project JP 95/09626-6), WWF-Brasil, Fundação O Boticário de Proteção à Natureza, International Foundation for Science (IFS), Idea Wild, CYTED (UNESCO), and FUNDUNESP (00105/04-DFP) provided financial support. We also thank Fundação Florestal do Estado de São Paulo for the permission to work at Intervales. The authors receive fellowships from the Brazilian Research Council (CNPq).

\section{References}

ALEIXO, A. \& GALETTI, M. 1997. The conservation of the avifauna in a lowland Atlantic Forest in south-east Brazil. Bird Cons. Int. 7:235-261.

ALMEIDA-NETO, M., CAMPASSI, F., GALETTI, M., JORDANO, P. \& OLIVEIRA-FILHO, A. 2008. Vertebrate dispersal syndromes along the Atlantic forest: broad-scale patterns and macroecological correlates. Global Ecol. Biogeogr. 17:503-513.

ALMEIDA-SCABBIA, R. 1996. Fitossociologia de um trecho de Mata Atlântica no sudeste do Brasil. MSc thesis, Universidade Estadual Paulista, Rio Claro, Brazil.

ASSOCIATION OF OFFICIAL ANALYTICAL CHEMISTS -AOAC. 1990. Official methods of analysis. $15^{\text {th }}$ ed. Washington.

BLIGH, E.G. \& DYER, W.J. 1959. A rapid method of total lipid extraction and purification. Can. J. Biochem. Physiol. 37:911-917.

BOROWICZ, V.A. 1988. Fruit consumption by birds in relation to fat content of pulp. Am. Midl. Nat. 119:121-127.

CIPOLLINI, M.L. \& LEVEY, D.J. 1997. Why are some fruits toxic? Glycoalkaloids in Solanum and fruit choice by vertebrates. Ecology 78:782-798. 
CAZETTA, E., SCHAEFFER, U.M. \& GALETTI, M. 2008. Does attraction to frugivores or defense against pathogens shape fruit pulp composition? Oecologia 155:277-286.

CLARK, D.B. 1996. Abolishing virginity. J. Trop. Ecol. 12:735-739.

CORLETT, R.T. 1996. Characteristics of vertebrate-dispersed fruits in Hong Kong. J. Trop. Ecol. 12:819-833.

DEBUSSCHE, M. \& ISENMANN, P. 1989. Fleshy fruit characters and the choices of birds and mammal seed dispersers in a Mediterranean region. Oikos 56:327-338.

DEBUSSCHE, M., CORTEZ, J. \& RIMBAULT, I. 1987. Variation in fleshy fruit composition in the Mediterranean region: the importance of ripening season, life-form, fruit type, and geographical distribution. Oikos 49:244-252.

DONATTI, C.I., GAlETTI, M., PIZO, M.A., GUIMARÃES Jr., P.R. \& JORDANO, P. 2007. Living in the land of ghosts: fruit traits and the importance of large mammals as seed dispersers in the Pantanal, Brazil. In Seed dispersal: theory and its application in a changing world (A.J. Dennis, E.W. Schupp, R.J. Green \& D.W. Westcott, ed.). CABI Publishing, Wallingford, Inglaterra, p.104-123.

DOWSETT-LEMAIRE, F. 1988. Fruit choice and seed dissemination by birds and mammals in the evergreen forests of upland Malawi. Rev. Ecol. (Terre et Vie) 43:251-285.

ERIKSSON, O. \& EHRLÉN, J. 1991. Phenological variation in fruit characteristics in vertebrate-dispersed plants. Oecologia 86:463-470.

FELSENSTEIN, J. 1985. Phylogenies and the comparative method. Am. Nat. 125:1-15.

GALETTI, M. 1996. Fruits and frugivores in a Brazilian Atlantic forest. PhD Thesis, University of Cambridge, Cambridge, UK.

GALETTI, M., MARTUSCELLI, P., OLMOS, F. \& ALEIXO, A. 1997. Ecology and conservation of the jacutinga Pipile jacutinga in the Atlantic forest of Brazil. Biol. Cons. 82:31-39.

GALETTI, M., LAPS, R. \& PIZO, M.A. 2000. Frugivory by toucans (Ramphastidae) in two altitudes in the Atlantic forest of Brazil. Biotropica 32:842-850.

GAUTIER-HION, A., DUPLANTIER, J.M., QURIS, R., FEER, F., SOURD, C., DECOUX, J.P., DUBOST, G., EMMONS, L., ERARD, C., HECKETSWEILER, P., MOUNGAZI, A., ROUSSILHON, C. \& THIOLLAY, J.M. 1985. Fruit characters as a basis of fruit choice and seed dispersal in a tropical forest vertebrate community. Oecologia 65:324-327.

GIRÃO, L.C., LOPES, A.V., TABARELLI, M., BRUNA, E.M. \& CHAVE, J. 2007. Changes in tree reproductive traits reduce functional diversity in a fragmented Atlantic Forest landscape. Plos One 2:e908.

GUILHERME, F.A.G., MORELLATO, L.P.C. \& ASSIS, M.A. 2004. Horizontal and vertical tree community structure in a lowland Atlantic Rain Forest, Southeastern Brazil. Rev. Bras. Bot. 27:725- 37.

HERRERA, C.M. 1981. Are tropical fruits more rewarding to dispersers than temperate ones? Am. Nat. 118:896-907.

HERRERA, C.M. 1982. Defense of ripe fruits from pests: its significance in relation to plant-disperser interactions. Am Nat 120:218-241.

HERRERA, C.M. 1987. Vertebrate-dispersed plants of the Iberian Peninsula: a study of fruit characteristics. Ecol. Monogr. 57:305-331.

HERRERA, C.M. 1989. Frugivory and seed dispersal by carnivorous mammals, and associated fruit characteristics, in undisturbed Mediterranean habitats. Oikos 55:250-262.

HERRERA, C.M. 2002. Seed dispersal by vertebrates. In Plant-animal interactions: an evolutionary approach (C.M. Herrera \& O. Pellmyr, eds.). Blackwell Publishing, Malden, USA, p.185-208.

HOOPER, D.U. \& VITOUSEK, P.M. 1997. The effects of plant composition and diversity on ecosystem processes. Science 277:1302-1305.

IZAR, P. 1999. Aspectos de ecologia e comportamento de um grupo de macacos-prego (Cebus apella) em área de Mata Atlântica, São Paulo. PhD thesis, Universidade de São Paulo, São Paulo, Brazil.

JACOMASSA, F.A.F. \& PIZO, M.A. 2010. Birds and bats diverge in the qualitative and quantitative components of seed dispersal of a pioneer tree. Acta Oecologica 36:493-496.

JANSON, C.H. 1983. Adaptation of fruit morphology to dispersal agents in a neotropical forest. Science 219:187-189.

JOHNSON, R.A., WILLSON, M.F. \& THOMPSON, J.N. 1985. Nutritional value of wild fruits and consumption by migrant frugivorous birds. Ecology 66:819-827.
JORDANO, P. 1995. Angiosperm fleshy fruits and seed dispersers: a comparative analysis of adaptation and constraints in plant-animal interactions. Am. Nat. 145:163-191.

JORDANO, P. 2000. Fruits and frugivory. In Seeds: the ecology of regeneration in plant communities (M. Fenner, ed.). $2^{\text {nd }}$ ed. CAB International, Wallingford, UK, p.125-165.

KITAMURA, S., YUMOTO, T., POONSWAD, P., CHUAILUA, P., PLONGMAI, K., MARUHASHI, T. \& NOMA, N. 2002. Interactions between fleshy fruits and frugivores in a tropical seasonal forest in Thailand. Oecologia, 133:559-572.

KNIGHT, R.S. \& SIEGFRIED, W.R. 1983. Inter-relationship between type, size and colour of fruits and dispersal in Souther African trees. Oecologia 56:405-412.

LOMÁSCOLO, S.B. \& SCHAEFER, H.M. 2010. Signal convergence in fruits: a result of selection by frugivores? J. Evol. Biol. 23:614-624.

LONG, R.W. 1971. A flora of tropical Florida. University of Miami Press, Coral Gables, Florida.

MULLER-LANDAU, H.C., WRIGHT, S.J., CALDERÓN, O., CONDIT, R. \& HUBBELL, S.P. 2008. Interspecific variation in primary seed dispersal in a tropical forest. J. Ecol. 96:653-667.

NAKANISHI, H. 1996. Fruit color and fruit size of bird-disseminated plants in Japan. Vegetatio 123:207-218.

PIZO, M.A. 2002. The seed dispersers and fruit syndromes of Myrtaceae in the Brazilian Atlantic forest. In Seed dispersal and frugivory: ecology, evolution and conservation (D.J. Levey, W.R. Silva \& M. Galetti, ed.). CABI Publishing, Wallingford, Oxfordshire, UK, p.129-143.

PIZO, M.A. 2003. Padrão de deposição de sementes e sobrevivência de sementes e plântulas de duas espécies de Myrtaceae na Mata Atlântica. Rev. Brasil. Bot. 26:371-377.

RIBEIRO, M.C., METZGER, J.P., MARTENSEN, A.C., PONZONI, F.J. \& HIROTA, M.M. 2009. The Brazilian Atlantic Forest: how much is left, and how is the remaining forest distributed? Implications for conservation. Biol. Cons. 142:1141-1153.

RODRIGUES, M., OLMOS, F. \& GALETTI, M. 1993. Seed dispersal by tapir in southeastern Brazil. Mammalia 57:460-461.

SNOW, D. 1981. Tropical frugivorous birds and their food plants: a world survey. Biotropica 13:1-14

SNOW, B.K. \& SNOW, D.W. 1988. Birds and berries. T. \& A.D. Poyser, Calton, UK.

STATSOFT. 1996. Statistica for Windows: computer program manual. Statisoft Inc., Tulsa, USA.

STILES, E.W. 1980. Patterns of fruit presentation and seed dispersal in bird-disseminated woody plants in the eastern deciduous forest. Am. Nat. 116:670-688

STILES, E.W. 1993. The influence of pulp lipids on fruit preference by birds. Vegetatio 107-108:227-235

TRAVESET, A., WILLSON, M.F. \& VERDU, M. 2004. Characteristics of fleshy fruits in southeast Alaska: phylogenetic comparison with fruits from Illinois. Ecography 27:41-48.

VAN DER PIJL, L. 1982. Principles of seed dispersal in higher plants. $3^{\text {rd }}$ ed. Springer-Velag, Berlin.

VIEIRA, E.M. \& IZAR, P. 1999. Interactions between aroids and arboreal mammals in the Brazilian Atlantic rainforest. Plant Ecol. 145:75-82.

WHEELWRIGHT, N.T., HABER, W.A., MURRAY, K.G. \& GUINDON, C. 1984. Tropical fruit-eating birds and their food plants: a survey of a Costa Rican lower montane forest. Biotropica 16:173-192.

WHEELWRIGHT, N.T. \& JANSON, C.H. 1985. Colors of fruit displays of bird-dispersed plants in two tropical forests. Am. Nat. 126:777-799.

WILLSON, M.F. \& THOMPSON, J.N. 1982. Phenology and ecology of color in bird-dispersed fruits, or why some fruits are red when they are "green". Can. J. Bot. 60:701-713.

WILLSON, M.F., IRVINE, A.K. \& WALSH, N.G. 1989. Vertebrate dispersal syndromes in some Australian and New Zealand plant communities, with geographic comparisons. Biotropica 21:133-147.

ZIPPARRO, V.B., GUILHERME, F.A.G., ALMEIDA-SCABBIA, R.J. \& MORELLATO, L.P.C. 2005. Levantamento florístico de floresta atlântica no sul do estado de São Paulo (Parque Estadual Intervales, Base Saibadela, Sete Barras). Biota Neotropica. 5: http://www.biotaneotropica.org.br/ v5n1/pt/fullpaper?bn02605012005+pt 


\section{Appendix}

Appendix 1. Growth form, colour, and mean morphological measures of vertebrate-dispersed fruits of the Saibadela forest. Values are based on at least ten fruits per species. Values for mean seed number and fruit and seed dimensions were rounded to the nearest integer. Species with temporally bicolored fruits are indicated by asterisks.

\begin{tabular}{|c|c|c|c|c|c|c|c|c|c|c|c|}
\hline Family & Species & $\begin{array}{c}\text { Growth } \\
\text { form }^{\mathrm{a}}\end{array}$ & $\begin{array}{c}\text { Fruit } \\
\text { colour }^{b}\end{array}$ & $\begin{array}{c}\text { No. } \\
\text { seeds/ } \\
\text { fruit }\end{array}$ & $\begin{array}{c}\text { Seed } \\
\text { width } \\
(\mathrm{mm})\end{array}$ & $\begin{array}{c}\text { Seed } \\
\text { length } \\
(\mathrm{mm})\end{array}$ & $\begin{array}{l}\text { Fruit } \\
\text { width } \\
(\mathrm{mm})\end{array}$ & $\begin{array}{c}\text { Fruit } \\
\text { length } \\
(\mathbf{m m})\end{array}$ & $\begin{array}{c}\text { Seed } \\
\text { mass } \\
(\mathrm{g})\end{array}$ & $\begin{array}{c}\text { Fruit } \\
\text { mass } \\
(\mathrm{g})\end{array}$ & $\begin{array}{c}\begin{array}{c}\text { Disperser } \\
\text { group }^{c}\end{array}\end{array}$ \\
\hline \multirow[t]{3}{*}{ Annonaceae } & Guatteria australis & $\mathrm{T}$ & $\begin{array}{c}\text { black/dark red } \\
(\mathrm{F} / \mathrm{P})\end{array}$ & 1 & 5 & 8 & 6 & 10 & 0.1 & 0.3 & $\mathrm{~b}$ \\
\hline & Rollinia sericea & $\mathrm{T}$ & yellow & $>50$ & 5 & 8 & 33 & 34 & $<0.1$ & 20.0 & $\mathrm{~m}$ \\
\hline & Xylopia brasiliensis & $\mathrm{T}$ & white/red (A/C) & - & - & - & - & - & - & - & $\mathrm{b}$ \\
\hline \multirow[t]{9}{*}{ Araceae } & Anthurium harrisi & M & pale green & - & - & - & - & - & $<0.1$ & - & $\mathrm{b}, \mathrm{m}$ \\
\hline & Anthurium langsdorffii & M & yellow & - & - & - & - & - & - & - & $\mathrm{b}$ \\
\hline & Anthurium pentaphylum & M & dark red & - & - & - & - & - & - & - & $\mathrm{b}, \mathrm{m}, \mathrm{s}$ \\
\hline & Anthurium scandens & M & white & 4 & 1 & 2 & 6 & 6 & $<0.1$ & 0.1 & $\mathrm{~b}, \mathrm{~m}$ \\
\hline & Heteropsis oblongifolia & M & orange & 4 & 6 & 14 & 14 & 16 & 0.4 & 2.1 & $\mathrm{~b}, \mathrm{~m}$ \\
\hline & Monstera adansonii & M & white & 1 & - & - & 8 & 11 & 0.2 & 0.4 & $\mathrm{~b}, \mathrm{~m}, \mathrm{~s}$ \\
\hline & $\begin{array}{l}\text { Philodendron } \\
\text { appendiculatum }\end{array}$ & M & pale green & - & $<1$ & 1 & - & - & $<0.1$ & - & $\mathrm{b}, \mathrm{m}, \mathrm{s}$ \\
\hline & $\begin{array}{l}\text { Philodendron } \\
\text { corcovadense }\end{array}$ & M & red & 1 & 2 & 3 & 6 & 9 & $<0.1$ & 0.2 & $\mathrm{~b}, \mathrm{~m}, \mathrm{~s}$ \\
\hline & $\begin{array}{l}\text { Philodendron } \\
\text { crassinervium }\end{array}$ & M & yellow & - & - & - & - & - & - & - & $\mathrm{b}, \mathrm{m}, \mathrm{s}$ \\
\hline \multirow[t]{2}{*}{ Araliaceae } & $\begin{array}{l}\text { Didymopanax } \\
\text { angustissimum }\end{array}$ & $\mathrm{T}$ & brown & - & - & - & 9 & 7 & - & 0.2 & $\mathrm{~b}$ \\
\hline & Dendropanax sp. & M & green & 5 & 1 & 3 & 4 & 4 & - & 1.0 & $\mathrm{~b}$ \\
\hline \multirow[t]{5}{*}{ Arecaceae } & $\begin{array}{c}\text { Astrocaryum } \\
\text { aculeatissimum }\end{array}$ & $\mathrm{T}$ & brown & 1 & - & - & 35 & 60 & - & 29.5 & $\mathrm{r}$ \\
\hline & Bactris setosa & $\mathrm{T}$ & pale green & 1 & 10 & 13 & 15 & 15 & 1.4 & 2.7 & $\mathrm{r}$ \\
\hline & Euterpe edulis & $\mathrm{T}$ & black & 1 & 11 & 12 & 14 & 14 & 1.3 & 1.7 & $\mathrm{~b}, \mathrm{~m}, \mathrm{u}$ \\
\hline & Geonoma gamiova & $S$ & black & 1 & 7 & 9 & 10 & 12 & 0.3 & 0.8 & $\mathrm{~b}$ \\
\hline & Geonoma pauciflora & S & black & 1 & 6 & 7 & 8 & 9 & 0.2 & 0.5 & $\mathrm{~b}$ \\
\hline Bignoniaceae & Schlegelia parviflora & $\mathrm{L}$ & dark red & 45 & 1 & 3 & 9 & 8 & $<0.1$ & 0.3 & $\mathrm{~b}, \mathrm{~m}$ \\
\hline Boraginaceae & Cordia sylvestris & $\mathrm{T}$ & red & 1 & 4 & 5 & 10 & 10 & 0.1 & 0.6 & $\mathrm{~b}, \mathrm{~m}$ \\
\hline Bromeliaceae & Aechmea nudicaulis & $\mathrm{E}$ & $\begin{array}{c}\text { orange/pink } \\
(\mathrm{F} / \mathrm{B}-\mathrm{T})\end{array}$ & $>50$ & $<1$ & $<1$ & 7 & 16 & $<0.1$ & 0.2 & $\mathrm{~b}$ \\
\hline Burseraceae & Protium widgrenii & $\mathrm{T}$ & white/red (A/C) & 1 & 9 & 16 & 12 & 16 & 0.1 & 1.0 & $\mathrm{~b}, \mathrm{~m}$ \\
\hline \multirow[t]{2}{*}{ Cactaceae } & Rhipsalis sp. & $\mathrm{E}$ & white & 10 & $<1$ & $<1$ & 5 & 4 & $<0.1$ & $<0.1$ & $\mathrm{~b}$ \\
\hline & Rhipsalis sp. & $\mathrm{E}$ & pink & - & $<1$ & $<1$ & - & - & $<0.1$ & - & $\mathrm{b}$ \\
\hline \multirow[t]{4}{*}{ Caesalpiniaceae } & Copaifera langsdorfii & $\mathrm{T}$ & yellow/black (A/S) & 1 & 9 & 11 & - & - & 0.6 & 1.3 & $\mathrm{~b}, \mathrm{~m}$ \\
\hline & Copaifera trapezifolia & $\mathrm{T}$ & red/black (A/S) & 1 & 8 & 13 & 23 & 31 & 2.0 & 2.9 & $\mathrm{~b}, \mathrm{~m}$ \\
\hline & Hymenaea altissima & $\mathrm{T}$ & brown & - & - & - & - & - & - & - & $\mathrm{r}$ \\
\hline & Swartzia flaemingii & $\mathrm{T}$ & $\begin{array}{c}\text { yellow/brown } \\
\text { (A/S) }\end{array}$ & 1 & 35 & 67 & - & - & 29.0 & - & $\mathrm{r}$ \\
\hline Canellaceae & Cinnamodendron dinizii & $\mathrm{T}$ & black & 2 & 9 & 10 & 14 & 16 & 0.5 & 2.3 & $\mathrm{~b}, \mathrm{~m}$ \\
\hline Caricaceae & Jacaratia spinosa & $\mathrm{T}$ & orange & $>50$ & 5 & 6 & 42 & 68 & $<0.1$ & 50.0 & $\mathrm{~m}$ \\
\hline \multirow[t]{4}{*}{ Cecropiaceae } & Cecropia glaziovii & $\mathrm{T}$ & orange & $>50$ & - & - & - & - & - & - & $\mathrm{a}, \mathrm{b}, \mathrm{m}, \mathrm{s}$ \\
\hline & Cecropia pachystachia & $\mathrm{T}$ & green & $>50$ & 1 & 3 & - & - & $<0.1$ & $<0.1$ & $\mathrm{~b}, \mathrm{~m}$ \\
\hline & Coussapoa microcarpa & $\mathrm{T}$ & green & 1 & 12 & 17 & 17 & 17 & $<0.1$ & $<0.1$ & $\mathrm{~b}$ \\
\hline & Pourouma guianensis & $\mathrm{T}$ & black & 1 & - & - & 18 & 17 & 1.2 & 3.3 & $\mathrm{~b}, \mathrm{~m}$ \\
\hline \multirow[t]{5}{*}{ Celastraceae } & Maytenus aquifolium & $\mathrm{T}$ & white/yellow (A/C) & 3 & 7 & 8 & 13 & 16 & 1.3 & 2.7 & $\mathrm{~b}$ \\
\hline & Maytenus alanternoides & $\mathrm{T}$ & white/yellow (A/C) & 2 & 9 & 11 & 14 & 12 & 0.4 & 0.6 & $\mathrm{~b}$ \\
\hline & Maytenus ligustrina & $\mathrm{T}$ & white/red (A/C) & 1 & 8 & 12 & 14 & 25 & - & - & $\mathrm{b}$ \\
\hline & Maytenus robusta & $\mathrm{T}$ & white/yellow (A/C) & 1 & 4 & 13 & 10 & 15 & 0.2 & 0.6 & $\mathrm{~b}$ \\
\hline & Maytenus schumanniana & $\mathrm{S}$ & white/brown (A/C) & 1 & 7 & 8 & 8 & 11 & 0.1 & 0.3 & $\mathrm{~b}$ \\
\hline Chrysobalanaceae & Parinari excelsa & $\mathrm{T}$ & brown & 1 & 16 & 28 & 25 & 39 & 5.6 & 12.9 & $\mathrm{~m}$ \\
\hline \multirow[t]{2}{*}{ Clusiaceae } & Clusia parviflora & $\mathrm{E}$ & red/white $(\mathrm{A} / \mathrm{C})$ & 5 & 2 & 4 & 5 & 8 & $<0.1$ & 0.1 & $\mathrm{~b}, \mathrm{~m}$ \\
\hline & Garcinia gardneriana & $\mathrm{T}$ & yellow & 1 & 14 & 27 & 28 & 35 & 2.9 & 13.7 & $\mathrm{~m}, \mathrm{r}$ \\
\hline \multirow[t]{2}{*}{ Commelinaceae } & Dychorisandra thyrsiflora & $\mathrm{H}$ & white/red (A/C) & - & - & - & - & - & - & - & $\mathrm{b}$ \\
\hline & Dichorisandra sp. & $\mathrm{H}$ & orange & 5 & - & - & 6 & 12 & - & 0.2 & $\mathrm{~b}$ \\
\hline
\end{tabular}

${ }^{\mathrm{a}}$ Growth form: $\mathrm{E}=$ epiphyt, $\mathrm{H}=$ herb, $\mathrm{L}=$ liana, $\mathrm{M}=$ hemiepiphyt, $\mathrm{S}=$ shrub, $\mathrm{T}=$ tree; ${ }^{\mathrm{b} B i c o l o r e d ~ f r u i t s ~ a r e ~ i n d i c a t e d ~ b y ~ t w o-c o l o u r ~ c o m b i n a t i o n s ; ~ f o r ~}$ the temporally bicolored fruits (indicated by asterisks in the species column), these colors correspond, respectively, to the ripe and unripe fruits, for the morphologically bicolored fruits the colors represent, respectively, the colour of the flesh part and the accessory(ies) structure(s) followed by capital letters (in parentheses) that indicate to which structures the preceding colours refer to: $\mathrm{A}=$ aril, $\mathrm{B}=$ bracts, $\mathrm{C}=$ capsule, $\mathrm{F}=$ fruit, $\mathrm{P}=$ pedicel, $\mathrm{S}=$ seed, $\mathrm{T}=$ infructescence stem, $\mathrm{Y}=$ calyx; ${ }^{\mathrm{c}}$ Seed disperser groups: $\mathrm{a}=\mathrm{bat}, \mathrm{b}=$ bird, $\mathrm{m}=$ monkey, $\mathrm{r}=$ rodent, $\mathrm{s}=$ marsupial, $\mathrm{u}=$ ungulate . 
Appendix 1. Continued...

\begin{tabular}{|c|c|c|c|c|c|c|c|c|c|c|c|}
\hline Family & Species & $\begin{array}{c}\text { Growth } \\
\text { form }^{\mathrm{a}}\end{array}$ & $\begin{array}{c}\text { Fruit } \\
\text { colour }^{b}\end{array}$ & $\begin{array}{c}\text { No. } \\
\text { seeds/ } \\
\text { fruit }\end{array}$ & $\begin{array}{c}\text { Seed } \\
\text { width } \\
(\mathrm{mm})\end{array}$ & $\begin{array}{c}\text { Seed } \\
\text { length } \\
(\mathrm{mm})\end{array}$ & $\begin{array}{l}\text { Fruit } \\
\text { width } \\
\text { (mm) }\end{array}$ & $\begin{array}{c}\text { Fruit } \\
\text { length } \\
(\mathbf{m m})\end{array}$ & $\begin{array}{c}\text { Seed } \\
\text { mass } \\
(\mathrm{g})\end{array}$ & $\begin{array}{c}\text { Fruit } \\
\text { mass } \\
(\mathrm{g})\end{array}$ & $\begin{array}{c}\text { Disperser } \\
\text { group }^{c}\end{array}$ \\
\hline Costaceae & Costus spiralis & $\mathrm{H}$ & white/red (F/B) & - & - & - & - & - & - & - & $\mathrm{b}$ \\
\hline \multirow[t]{2}{*}{ Elaeocarpaceae } & Sloanea guianensis & $\mathrm{T}$ & red & 1 & 6 & 11 & 7 & 12 & 0.2 & 0.3 & $\mathrm{~b}, \mathrm{~m}$ \\
\hline & Sloanea monosperma & $\mathrm{T}$ & white & - & - & - & - & - & - & - & $\mathrm{b}$ \\
\hline \multirow[t]{5}{*}{ Euphorbiaceae } & Alchornea glandulosa & $\mathrm{T}$ & red & 2 & - & - & 5 & 5 & $<0.1$ & 0.1 & $\mathrm{~b}$ \\
\hline & Alchornea triplinervia & $\mathrm{T}$ & red & 2 & 4 & 5 & 8 & 11 & 0.1 & 0.4 & $\mathrm{~b}$ \\
\hline & Hyeronima alchorneoides & $\mathrm{T}$ & dark red & 1 & 2 & 3 & 4 & 5 & $<0.1$ & $<0.1$ & $\mathrm{~b}, \mathrm{~m}$ \\
\hline & Tetrorchidium rubrivenium & $\mathrm{T}$ & red & 1 & 5 & 5 & 6 & 6 & $<0.1$ & $<0.1$ & $\mathrm{~b}$ \\
\hline & Margaritaria nobilis & $\mathrm{T}$ & iridescent blue & 3 & 7 & 11 & 7 & 11 & 0.2 & 0.8 & $\mathrm{~b}$ \\
\hline \multirow[t]{2}{*}{ Flacourtiaceae } & Casearia decandra & $\mathrm{T}$ & yellow & 2 & 6 & 6 & 10 & 11 & 0.1 & 0.7 & $\mathrm{~b}$ \\
\hline & Xylosma glaberrimum & $\mathrm{T}$ & red & - & - & - & - & - & - & - & $\mathrm{b}$ \\
\hline Gesneriaceae & Codonanthe sp. & $\mathrm{E}$ & orange & - & $<1$ & 1 & - & - & $<0.1$ & - & $\mathrm{b}$ \\
\hline \multirow[t]{2}{*}{ Heliconiaceae } & Heliconia rivularis & $\mathrm{H}$ & blue/orange (F/B) & - & - & - & - & - & - & - & $\mathrm{b}$ \\
\hline & Heliconia velloziana & $\mathrm{H}$ & blue/red (F/B) & - & - & - & - & - & - & - & $\mathrm{b}$ \\
\hline \multirow[t]{3}{*}{ Hippocrateaceae } & Cheiloclinium cognatum. & $\mathrm{L}$ & yellow & 2 & 21 & 39 & 44 & 61 & 6.2 & 51.0 & $\mathrm{~m}$ \\
\hline & Cheiloclinium sp. & L. & gray & 5 & 22 & 26 & 50 & 65 & 4.4 & 72.7 & $\mathrm{~m}$ \\
\hline & Salacia elliptica & $\mathrm{L}$ & orange & 2 & - & - & 38 & 35 & - & 26.0 & $\mathrm{~m}$ \\
\hline Icacinaceae & Citronella megaphylla & $\mathrm{T}$ & black & 1 & 14 & 17 & 18 & 20 & 2.1 & 20.2 & $\mathrm{~b}$ \\
\hline \multirow[t]{7}{*}{ Lauraceae } & $\begin{array}{c}\text { Cryptocarya } \\
\text { archersoniana }\end{array}$ & $\mathrm{T}$ & yellow & 1 & 20 & 21 & 25 & 25 & 4.0 & 8.0 & $\mathrm{~m}$ \\
\hline & Cryptocarya moschata & $\mathrm{T}$ & yellow & 1 & 15 & 22 & 20 & 24 & 2.4 & 5.0 & $\mathrm{~b}, \mathrm{~m}$ \\
\hline & Endlicheria paniculata $*$ & $\mathrm{~T}$ & black/red (F/P) & 1 & - & - & 10 & 20 & - & - & $\mathrm{b}, \mathrm{m}$ \\
\hline & Nectandra megapotamica & $\mathrm{T}$ & black & 1 & 9 & 8 & 9 & 12 & 2.5 & 4.5 & $\mathrm{~b}$ \\
\hline & Ocotea dispersa & $\mathrm{T}$ & black/red (F/P) & 1 & 7 & 8 & 9 & 14 & 0.3 & 0.7 & $\mathrm{~b}$ \\
\hline & Ocotea tabacifolia & $\mathrm{T}$ & black & 1 & - & - & - & - & - & - & $\mathrm{b}$ \\
\hline & Ocotea teleiandra & $\mathrm{T}$ & black & 1 & 13 & 20 & 14 & 22 & 1.9 & 2.8 & $\mathrm{~b}$ \\
\hline \multirow[t]{2}{*}{ Loganiaceae } & Strychnos brasiliensis. & $\mathrm{T}$ & red & 1 & 12 & 11 & 15 & 15 & 1.0 & 2.0 & $\mathrm{~b}$ \\
\hline & Strychnos trinervis & $\mathrm{L}$ & orange & - & - & - & - & - & - & - & $\mathrm{b}$ \\
\hline Magnoliaceae & Talauma ovata & $\mathrm{T}$ & red/white (A/C) & $>50$ & 8 & 12 & 9 & 14 & 0.2 & 0.5 & $\mathrm{~b}$ \\
\hline Marantaceae & Stromanthe sanguineo & $\mathrm{H}$ & $\begin{array}{l}\text { orange/black } \\
\text { (A/S-C) }\end{array}$ & 1 & - & - & - & - & - & - & $\mathrm{b}$ \\
\hline Marcgraviaceae & Marcgravia polyantha & $\mathrm{L}$ & Red & $>50$ & $<1$ & $<1$ & 15 & 18 & $<0.1$ & 2.5 & $\mathrm{~b}, \mathrm{~m}$ \\
\hline \multirow[t]{9}{*}{ Melastomataceae } & Clidemia blepharodes & $\mathrm{E}$ & $\begin{array}{l}\text { Pale blue/red(F/ } \\
\text { B-Y) }\end{array}$ & $>50$ & $<1$ & $<1$ & 5 & 7 & $<0.1$ & 0.1 & $\mathrm{~b}$ \\
\hline & Leandra reversa & S & black & - & $<1$ & $<1$ & - & - & $<0.1$ & - & $\mathrm{b}$ \\
\hline & Leandra mosenii & S & black & - & $<1$ & $<1$ & - & - & $<0.1$ & - & $\mathrm{b}$ \\
\hline & Leandra glazioviana & S & black & - & $<1$ & $<1$ & - & - & $<0.1$ & - & $\mathrm{b}$ \\
\hline & Miconia cubatanensis & $\mathrm{T}$ & black & - & $<1$ & $<1$ & - & - & $<0.1$ & - & $\mathrm{b}$ \\
\hline & Miconia latecrenata & S & black & - & $<1$ & $<1$ & - & - & $<0.1$ & - & $\mathrm{b}$ \\
\hline & Miconia tristis & $\mathrm{T}$ & Blue & - & $<1$ & $<1$ & - & - & $<0.1$ & - & $\mathrm{b}$ \\
\hline & Mouriri chamissoana & $\mathrm{T}$ & orange & 1 & - & - & - & - & - & - & $\mathrm{b}$ \\
\hline & Ossaea retropila & S & black & - & $<1$ & $<1$ & - & - & $<0.1$ & - & $\mathrm{b}$ \\
\hline \multirow[t]{4}{*}{ Meliaceae } & Cabralea canjerana & $\mathrm{T}$ & orange/white (A/C) & 7 & 9 & 11 & 10 & 18 & 0.7 & 1.4 & $\mathrm{~b}$ \\
\hline & Guarea macrophylla & $\mathrm{T}$ & Red & 1 & - & - & 9 & 13 & - & 0.5 & $\mathrm{~b}$ \\
\hline & Trichilia lepidota & $\mathrm{T}$ & Red & - & - & - & - & - & - & - & $\mathrm{b}$ \\
\hline & Trichilia cf. pallens & $\mathrm{T}$ & red/black (A/S) & 2 & - & - & - & - & - & - & $\mathrm{b}$ \\
\hline Mendonciaceae & Mendoncia velloziana & $\mathrm{L}$ & black & 1 & 7 & 14 & 14 & 17 & 0.3 & 1.8 & $\mathrm{~b}$ \\
\hline \multirow[t]{2}{*}{ Menispermaceae } & Abuta selloana & $\mathrm{L}$ & yellow & 1 & 11 & 16 & 17 & 32 & - & 5.7 & $\mathrm{~m}$ \\
\hline & Hyperbaena sp. & $\mathrm{L}$ & black & - & - & - & - & - & - & - & $\mathrm{b}, \mathrm{m}$ \\
\hline Mimosaceae & Inga $\mathrm{sp}$. & $\mathrm{T}$ & brown & 7 & 9 & 16 & 20 & 101 & 0.4 & 22.0 & $\mathrm{~m}$ \\
\hline \multirow[t]{3}{*}{ Monimiaceae } & Mollinedia schottiana & $\mathrm{T}$ & black & 1 & - & - & - & - & - & - & $\mathrm{b}$ \\
\hline & Mollinedia uleana & $\mathrm{T}$ & Gray & 1 & 9 & 18 & 13 & 21 & 0.9 & 2 & $\mathrm{~b}$ \\
\hline & Mollinedia sp. & $\mathrm{T}$ & black & 1 & 7 & 10 & 9 & 12 & 0.4 & 0.8 & $\mathrm{~b}$ \\
\hline \multirow[t]{5}{*}{ Moraceae } & Ficus enormis & M & green & $>50$ & $<1$ & $<1$ & 14 & 14 & $<0.1$ & 1.3 & $\mathrm{~b}, \mathrm{~m}$ \\
\hline & Ficus gomelleira & $\mathrm{T}$ & green & $>50$ & $<1$ & $<1$ & 17 & 19 & $<0.1$ & 2.8 & $\mathrm{~b}, \mathrm{~m}$ \\
\hline & Ficus insipida & $\mathrm{T}$ & green & $>50$ & $<1$ & $<1$ & 34 & 35 & $<0.1$ & 19.0 & $\mathrm{~b}, \mathrm{~m}$ \\
\hline & Ficus sp. & $\mathrm{T}$ & green & $>50$ & $<1$ & $<1$ & 17 & 17 & $<0.1$ & 2.5 & $\mathrm{~b}, \mathrm{~m}$ \\
\hline & Ficus sp. & $\mathrm{T}$ & green & $>50$ & $<1$ & $<1$ & 13 & 13 & $<0.1$ & 1.0 & $\mathrm{~b}, \mathrm{~m}$ \\
\hline
\end{tabular}

${ }^{\mathrm{a}}$ Growth form: $\mathrm{E}=$ epiphyt, $\mathrm{H}=$ herb, $\mathrm{L}=$ liana, $\mathrm{M}=$ hemiepiphyt, $\mathrm{S}=$ shrub, $\mathrm{T}=$ tree; ${ }^{\mathrm{b} B i c o l o r e d ~ f r u i t s ~ a r e ~ i n d i c a t e d ~ b y ~ t w o-c o l o u r ~ c o m b i n a t i o n s ; ~ f o r ~}$ the temporally bicolored fruits (indicated by asterisks in the species column), these colors correspond, respectively, to the ripe and unripe fruits, for the morphologically bicolored fruits the colors represent, respectively, the colour of the flesh part and the accessory(ies) structure(s) followed by capital letters (in parentheses) that indicate to which structures the preceding colours refer to: $\mathrm{A}=$ aril, $\mathrm{B}=$ bracts, $\mathrm{C}=$ capsule, $\mathrm{F}=$ fruit, $\mathrm{P}=$ pedicel, $\mathrm{S}=$ seed,

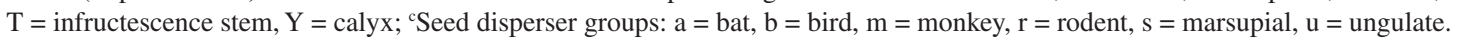


Appendix 1. Continued...

\begin{tabular}{|c|c|c|c|c|c|c|c|c|c|c|c|}
\hline Family & Species & $\begin{array}{c}\text { Growth } \\
\text { form }^{\mathrm{a}}\end{array}$ & $\begin{array}{c}\text { Fruit } \\
\text { colour }^{b}\end{array}$ & $\begin{array}{c}\text { No. } \\
\text { seeds/ } \\
\text { fruit }\end{array}$ & $\begin{array}{c}\text { Seed } \\
\text { width } \\
(\mathrm{mm})\end{array}$ & $\begin{array}{c}\text { Seed } \\
\text { length } \\
(\mathbf{m m})\end{array}$ & $\begin{array}{l}\text { Fruit } \\
\text { width } \\
(\mathrm{mm})\end{array}$ & $\begin{array}{c}\text { Fruit } \\
\text { length } \\
(\mathbf{m m})\end{array}$ & $\begin{array}{c}\text { Seed } \\
\text { mass } \\
(\mathrm{g})\end{array}$ & $\begin{array}{c}\text { Fruit } \\
\text { mass } \\
(\mathrm{g})\end{array}$ & $\begin{array}{c}\text { Disperser } \\
\text { group }^{c}\end{array}$ \\
\hline & Sorocea bonplandii & $\mathrm{T}$ & red & 1 & 8 & 11 & 12 & 13 & 0.6 & 1.2 & $\mathrm{~b}, \mathrm{~m}$ \\
\hline \multirow{2}{*}{ Myristicaceae } & Virola gardneri & $\mathrm{T}$ & red & 1 & 24 & 20 & 37 & 30 & 5.6 & 6.3 & $\mathrm{~b}, \mathrm{~m}$ \\
\hline & Virola bicuhyba & $\mathrm{T}$ & red & 1 & 15 & 24 & 15 & 24 & 2.3 & 3.5 & $\mathrm{~b}, \mathrm{~m}, \mathrm{u}$ \\
\hline Myrsinaceae & Myrsine umbellata & $\mathrm{T}$ & black & 1 & 6 & 7 & 8 & 8 & 0.2 & 0.4 & $\mathrm{~b}$ \\
\hline \multirow[t]{37}{*}{ Myrtaceae } & Calycorectes acutatus & $\mathrm{T}$ & yellow & 1 & 18 & 17 & 23 & 22 & 3.6 & 6.3 & $?$ \\
\hline & Calycorectes australis & $\mathrm{T}$ & red & 1 & 10 & 11 & 21 & 18 & 1.0 & 2.0 & $\mathrm{~b}$ \\
\hline & Calyptranthes lanceolata & $\mathrm{S}$ & dark red & 1 & 8 & 9 & 13 & 11 & 0.4 & 1.0 & $\mathrm{~b}$ \\
\hline & Campomanesia guaviroba & $\mathrm{T}$ & yellow & - & 6 & 8 & 22 & 17 & - & 5.0 & $\mathrm{~m}$ \\
\hline & Campomanesia neriiflora & $\mathrm{T}$ & yellow & 9 & 9 & 11 & 31 & 40 & 0.3 & 29.0 & $\mathrm{~m}$ \\
\hline & $\begin{array}{c}\text { Campomanesia } \\
\text { schlechtendaliana }\end{array}$ & $\mathrm{T}$ & yellow & 10 & 10 & 11 & 34 & 28 & 0.4 & 18.0 & $\mathrm{~m}$ \\
\hline & $\begin{array}{c}\text { Campomanesia } \\
\text { xanthocarpa }\end{array}$ & $\mathrm{T}$ & orange & 4 & 6 & 7 & 21 & 18 & 0.1 & 5.0 & $\mathrm{~b}, \mathrm{~m}$ \\
\hline & Eugenia bocainensis & $\mathrm{T}$ & red & 4 & 21 & 25 & 43 & 36 & 6.1 & 4.2 & $?$ \\
\hline & Eugenia cambucarana & $\mathrm{T}$ & green & 1 & 28 & 28 & 41 & 36 & 16.0 & 35.0 & $\mathrm{r}$ \\
\hline & Eugenia cuprea & $\mathrm{T}$ & red & 1 & 11 & 16 & 15 & 18 & 1.0 & 2.0 & $\mathrm{~b}$ \\
\hline & Eugenia handroana & $\mathrm{T}$ & black & 1 & 10 & 20 & 14 & 21 & 1.5 & 2.8 & $\mathrm{~b}$ \\
\hline & Eugenia melanogyna & $\mathrm{T}$ & dark red & 1 & 21 & 26 & 30 & 34 & 7.0 & 20.0 & $?$ \\
\hline & Eugenia mosenii & $\mathrm{T}$ & gray & 1 & 19 & 25 & 20 & 31 & 4.0 & 7.0 & $\mathrm{~b}$ \\
\hline & Eugenia multicostata & $\mathrm{T}$ & green & 1 & 24 & 25 & 30 & 27 & 4.0 & 10.0 & $\mathrm{r}$ \\
\hline & Eugenia neoglomerata & $\mathrm{T}$ & black & 1 & 14 & 17 & 17 & 19 & 2.0 & 3.0 & $\mathrm{~b}$ \\
\hline & Eugenia neoverrucosa & $\mathrm{T}$ & yellow & 1 & 29 & 30 & 47 & 44 & 14.0 & 41.0 & $\mathrm{r}$ \\
\hline & Eugenia oblongata & $\mathrm{T}$ & dark red & 1 & 15 & 17 & 25 & 21 & 1.0 & 6.0 & $\mathrm{~b}$ \\
\hline & Eugenia riedeliana & $\mathrm{T}$ & dark red & 1 & 12 & 15 & 21 & 15 & 1.0 & 4.0 & $\mathrm{~b}$ \\
\hline & Eugenia stictosepala & $\mathrm{T}$ & orange & 1 & 16 & 26 & 18 & 31 & 3.5 & 5.8 & $\mathrm{a}, \mathrm{m}$ \\
\hline & Eugenia sp. & $\mathrm{T}$ & orange & 1 & 16 & 17 & 25 & 21 & 25 & 7.7 & $?$ \\
\hline & Gomidesia anacardiifolia & $\mathrm{T}$ & dark red & 1 & 8 & 9 & 15 & 12 & 0.3 & 2.0 & $\mathrm{~b}$ \\
\hline & Gomidesia flagelaris & $\mathrm{T}$ & black & 1 & 10 & 10 & 15 & 14 & 1.5 & 2.0 & $\mathrm{~b}$ \\
\hline & Gomidesia spectabilis & $\mathrm{T}$ & gray & 1 & 11 & 11 & 16 & 16 & 0.6 & 3.0 & $\mathrm{~b}$ \\
\hline & Gomidesia tijucensis & $\mathrm{T}$ & dark red & 1 & 9 & 9 & 17 & 15 & 0.3 & 3.0 & $\mathrm{~b}$ \\
\hline & Marlierea eugeniopsoides & $\mathrm{T}$ & black & 1 & 13 & 11 & 18 & 16 & 1.0 & 3.2 & $\mathrm{~b}, \mathrm{~m}$ \\
\hline & Marlierea obscura & $\mathrm{T}$ & black & 2 & 7 & 9 & 14 & 11 & 0.2 & 2.0 & $\mathrm{~b}, \mathrm{~m}$ \\
\hline & Marlierea regeliana & $\mathrm{T}$ & black & 1 & 12 & 16 & 23 & 22 & 1.0 & 7.0 & $\mathrm{~b}, \mathrm{~m}$ \\
\hline & Marlierea suaveolens & $\mathrm{T}$ & dark red & 2 & 10 & 12 & 17 & 15 & 0.6 & 1.0 & $\mathrm{~b}, \mathrm{~m}$ \\
\hline & Marlierea tomentosa & $\mathrm{T}$ & black & 2 & 7 & 10 & 11 & 13 & 0.3 & 1.6 & $\mathrm{~b}, \mathrm{~m}$ \\
\hline & Myrceugenia myrcioides & $\mathrm{L}$ & orange & 2 & 8 & 3 & 14 & 17 & 0.1 & 2.0 & $\mathrm{~b}, \mathrm{~m}$ \\
\hline & Myrceugenia reitzii & $\mathrm{T}$ & gray & 4 & 7 & 12 & 17 & 20 & 0.3 & 4.0 & $\mathrm{~b}, \mathrm{~m}$ \\
\hline & Myrcia pubipetala & $\mathrm{T}$ & gray & 1 & 1 & 1 & 12 & 15 & 0.2 & 1.0 & $\mathrm{~b}, \mathrm{~m}$ \\
\hline & Myrciaria floribunda & $\mathrm{T}$ & black & 1 & - & - & 11 & - & - & - & $\mathrm{b}, \mathrm{m}$ \\
\hline & Neomitrantes glomerata & $\mathrm{T}$ & black & 2 & 11 & 14 & 19 & 15 & 1.0 & 4.0 & $\mathrm{~b}$ \\
\hline & Plinia complanata $*$ & $\mathrm{~T}$ & red/yellow & 1 & 9 & 7 & 12 & 10 & 0.2 & 1.0 & $\mathrm{~b}$ \\
\hline & Plinia pauciflora & $\mathrm{T}$ & red & - & - & - & - & - & - & - & $\mathrm{b}$ \\
\hline & Undetermined & $\mathrm{T}$ & red & 1 & 15 & 12 & 18 & 13 & 0.8 & 2.3 & $\mathrm{~b}$ \\
\hline Nyctaginaceae & Guapira oposita & $\mathrm{T}$ & black/red $(\mathrm{F} / \mathrm{P})$ & 1 & 6 & 10 & 11 & 13 & 0.3 & 1.1 & $\mathrm{~b}$ \\
\hline \multirow[t]{2}{*}{ Olacaceae } & Heisteria silvianii & $\mathrm{T}$ & white/red (F/B) & 1 & 12 & 13 & 10 & 13 & 0.4 & 0.9 & $\mathrm{~b}, \mathrm{~m}$ \\
\hline & $\begin{array}{l}\text { Tetrastylidium } \\
\text { grandifolium }\end{array}$ & $\mathrm{T}$ & green & 1 & 21 & 22 & 25 & 24 & 4.1 & 7.4 & $\mathrm{a}$ \\
\hline Phytolaccaceae & Phytolacca dioica & $\mathrm{T}$ & yellow & - & - & - & 7 & 9 & $<0.1$ & 0.3 & $\mathrm{~b}, \mathrm{~m}$ \\
\hline \multirow[t]{2}{*}{ Piperaceae } & Piper cernum & $\mathrm{S}$ & green & $>50$ & - & - & - & - & - & - & a \\
\hline & Piper aduncum & $S$ & green & $>50$ & - & - & - & - & - & - & $\mathrm{a}$ \\
\hline Quiinaceae & Quiina glaziovii & $\mathrm{T}$ & orange & 2 & 9 & 13 & 16 & 20 & 1.9 & 3.4 & $\mathrm{~m}$ \\
\hline Rhamnaceae & Rhamnidium elaeocarpum & $\mathrm{T}$ & dark red & - & - & - & - & - & - & - & $\mathrm{b}, \mathrm{m}$ \\
\hline \multirow[t]{5}{*}{ Rubiaceae } & Alibertia myrcifolia & $\mathrm{T}$ & dark red & - & - & - & - & - & - & - & $\mathrm{b}$ \\
\hline & Amaioua guianensis & $\mathrm{T}$ & red & - & - & - & 10 & 17 & - & - & $\mathrm{b}$ \\
\hline & Coccocypselum sp. & $\mathrm{H}$ & blue & 40 & 1 & 1 & 11 & 14 & $<0.1$ & 0.3 & $\mathrm{~b}$ \\
\hline & Coussarea contracta & $\mathrm{T}$ & red & 1 & 10 & 12 & 15 & 17 & 0.6 & 2.0 & $\mathrm{~b}, \mathrm{~m}$ \\
\hline & Geophila repens & $\mathrm{H}$ & orange & 2 & 3 & 5 & 7 & 9 & $<0.1$ & 0.3 & $\mathrm{~b}$ \\
\hline
\end{tabular}

${ }^{\mathrm{a}}$ Growth form: $\mathrm{E}=$ epiphyt, $\mathrm{H}=$ herb, $\mathrm{L}=$ liana, $\mathrm{M}=$ hemiepiphyt, $\mathrm{S}=$ shrub, $\mathrm{T}=$ tree; ${ }^{\mathrm{b} B i c o l o r e d ~ f r u i t s ~ a r e ~ i n d i c a t e d ~ b y ~ t w o-c o l o u r ~ c o m b i n a t i o n s ; ~ f o r ~}$ the temporally bicolored fruits (indicated by asterisks in the species column), these colors correspond, respectively, to the ripe and unripe fruits, for the morphologically bicolored fruits the colors represent, respectively, the colour of the flesh part and the accessory(ies) structure(s) followed by capital letters (in parentheses) that indicate to which structures the preceding colours refer to: $\mathrm{A}=$ aril, $\mathrm{B}=$ bracts, $\mathrm{C}=$ capsule, $\mathrm{F}=$ fruit, $\mathrm{P}=$ pedicel, $\mathrm{S}=$ seed, $\mathrm{T}=$ infructescence stem, $\mathrm{Y}=$ calyx; ${ }^{\mathrm{c}}$ Seed disperser groups: $\mathrm{a}=\mathrm{bat}, \mathrm{b}=$ bird, $\mathrm{m}=$ monkey, $\mathrm{r}=$ rodent, $\mathrm{s}=$ marsupial, $\mathrm{u}=$ ungulate. 
Appendix 1. Continued...

\begin{tabular}{|c|c|c|c|c|c|c|c|c|c|c|c|}
\hline Family & Species & $\begin{array}{c}\text { Growth } \\
\text { form }^{\mathrm{a}}\end{array}$ & $\begin{array}{c}\text { Fruit } \\
\text { colour }^{\mathrm{b}}\end{array}$ & $\begin{array}{c}\text { No. } \\
\text { seeds/ } \\
\text { fruit }\end{array}$ & $\begin{array}{c}\text { Seed } \\
\text { width } \\
(\mathrm{mm})\end{array}$ & $\begin{array}{c}\text { Seed } \\
\text { length } \\
(\mathrm{mm})\end{array}$ & $\begin{array}{l}\text { Fruit } \\
\text { width } \\
\text { (mm) }\end{array}$ & $\begin{array}{r}\text { Fruit } \\
\text { length } \\
(\mathrm{mm})\end{array}$ & $\begin{array}{c}\text { Seed } \\
\text { mass } \\
(\mathrm{g})\end{array}$ & $\begin{array}{c}\text { Fruit } \\
\text { mass } \\
(\mathrm{g})\end{array}$ & $\begin{array}{c}\text { Disperser } \\
\text { group }^{c}\end{array}$ \\
\hline & Ixora burchelliana & $\mathrm{T}$ & black & 2 & 5 & 6 & 8 & 8 & $<0.1$ & 0.3 & $\mathrm{~b}$ \\
\hline & Posoqueria latifolia & $\mathrm{T}$ & yellow & 2 & 12 & 12 & 36 & 49 & 0.8 & 29.2 & $\mathrm{~m}$ \\
\hline & Psychotria astrellantha $*$ & S & red/yellow & 2 & 3 & 3 & 8 & 7 & $<0.1$ & 0.2 & $\mathrm{~b}$ \\
\hline & Psychotria brachypoda & $\mathrm{S}$ & blue & 2 & 4 & 5 & 8 & 8 & 0.1 & 0.4 & $\mathrm{~b}$ \\
\hline & Psychotria mapourioides $*$ & $\mathrm{~T}$ & red/yellow & 2 & 2 & 3 & 5 & 6 & $<0.1$ & 0.1 & $\mathrm{~b}, \mathrm{~m}$ \\
\hline & Psychotria suterela & $\mathrm{T}$ & blue & 2 & 3 & 4 & 13 & 11 & $<0.1$ & 0.8 & $\mathrm{~b}, \mathrm{~m}$ \\
\hline & Randia nitida & $\mathrm{T}$ & yellow & - & - & - & - & 4 & - & - & $\mathrm{m}$ \\
\hline & Rudgea jasminoides * & $\mathrm{T}$ & red/yellow & 1 & 6 & 9 & 9 & 11 & 0.2 & 0.6 & $\mathrm{~b}$ \\
\hline & Rudgea recurva & $\mathrm{T}$ & white & - & - & - & - & - & - & - & $\mathrm{b}$ \\
\hline Rutaceae & Zanthoxyllum rhoifolium & $\mathrm{T}$ & red/black $(\mathrm{A} / \mathrm{S})$ & 1 & 2 & 3 & 4 & 4 & $<0.1$ & 0.1 & $\mathrm{~b}$ \\
\hline Sabiaceae & Meliosma sinuata & $\mathrm{T}$ & white & 1 & 11 & 14 & 21 & 29 & 1.1 & 5.2 & $\mathrm{~m}$ \\
\hline \multirow[t]{4}{*}{ Sapindaceae } & Allophylus petiolatus & $\mathrm{T}$ & red & 1 & 6 & 9 & 10 & 12 & 0.2 & 0.6 & $\mathrm{~b}$ \\
\hline & Cupania oblongifolia & $\mathrm{T}$ & yellow/black (A/S) & 3 & 10 & 17 & 11 & 17 & 1.1 & 1.4 & $\mathrm{~b}$ \\
\hline & Matayba elaeagnoides & $\mathrm{T}$ & yellow/black (A/S) & 3 & 7 & 11 & 15 & 19 & 0.5 & - & $\mathrm{b}$ \\
\hline & Paullinia sp. & $\mathrm{L}$ & white/black (A/S) & 1 & 8 & 11 & 10 & 11 & 0.3 & 0.5 & $\mathrm{~b}$ \\
\hline \multirow[t]{7}{*}{ Sapotaceae } & Chysophylum inornatum & $\mathrm{T}$ & black & 1 & 6 & 19 & 11 & 30 & 0.3 & 1.9 & $\mathrm{~b}, \mathrm{~m}$ \\
\hline & Chysophylum gonocarpum & $\mathrm{T}$ & black & 3 & - & - & - & - & - & - & $\mathrm{m}$ \\
\hline & Chrysophyllum viride & $\mathrm{T}$ & yellow & 3 & 5 & 20 & 20 & 30 & 2.0 & 4.0 & $\mathrm{~m}$ \\
\hline & Diploon cuspidatum & $\mathrm{T}$ & black & 1 & 14 & 17 & 21 & 21 & 2.0 & 5.3 & $\mathrm{~m}$ \\
\hline & Pouteria caimito & $\mathrm{T}$ & dark orange & 3 & - & - & - & - & - & 3.8 & $\mathrm{~m}$ \\
\hline & Pouteria psammophyla & $\mathrm{T}$ & yellow & - & - & - & - & - & - & - & $\mathrm{m}$ \\
\hline & Pouteria venosa & $\mathrm{T}$ & orange & 1 & - & - & 37 & 39 & - & 26.2 & $\mathrm{~m}$ \\
\hline Simaroubaceae & Picramnia gardneri & S & red & - & - & - & - & - & - & - & $\mathrm{b}$ \\
\hline \multirow[t]{3}{*}{ Solanaceae } & Cestrum amictum & $\mathrm{T}$ & black & - & - & - & - & - & - & - & $\mathrm{b}$ \\
\hline & Cyphomandra diplocos & S & yellow & $>100$ & 3 & 4 & 37 & 46 & - & 32.0 & $\mathrm{~m}$ \\
\hline & Solanum inaequale & $\mathrm{T}$ & green & $>50$ & 1 & 3 & 16 & 17 & - & 2.6 & $\mathrm{a}$ \\
\hline Symplocaceae & Symplocos sp. & $\mathrm{T}$ & dark red & 1 & 5 & 12 & 7 & 13 & 0.1 & 0.5 & $?$ \\
\hline Ulmacea & Trema micrantha & $\mathrm{T}$ & orange & 1 & - & - & - & - & - & - & $\mathrm{b}$ \\
\hline \multirow[t]{2}{*}{ Urticaceae } & Pillea rhizobola & S & orange & - & - & - & - & - & - & - & $\mathrm{b}$ \\
\hline & Urera bacifera & S & white/red (F/P) & 1 & 2 & 3 & 7 & 5 & $<0.1$ & 0.1 & $\mathrm{~b}$ \\
\hline \multirow[t]{3}{*}{ Verbenaceae } & Aegiphila selowiana & $\mathrm{T}$ & red & 1 & 3 & 6 & 5 & 13 & $<0.1$ & 0.2 & $\mathrm{~b}$ \\
\hline & Citharexylum myrianthum & $\mathrm{T}$ & red & 2 & 5 & 11 & 10 & 12 & 0.1 & 0.9 & $\mathrm{~b}$ \\
\hline & Vitex sp. & $\mathrm{T}$ & dark red & 1 & - & - & 19 & 20 & - & 3.9 & $\mathrm{~b}, \mathrm{~m}$ \\
\hline
\end{tabular}

${ }^{\mathrm{a}}$ Growth form: $\mathrm{E}=$ epiphyt, $\mathrm{H}=$ herb, $\mathrm{L}=$ liana, $\mathrm{M}=$ hemiepiphyt, $\mathrm{S}=$ shrub, $\mathrm{T}=$ tree; ${ }^{\mathrm{b} B i c o l o r e d ~ f r u i t s ~ a r e ~ i n d i c a t e d ~ b y ~ t w o-c o l o u r ~ c o m b i n a t i o n s ; ~ f o r ~}$ the temporally bicolored fruits (indicated by asterisks in the species column), these colors correspond, respectively, to the ripe and unripe fruits, for the morphologically bicolored fruits the colors represent, respectively, the colour of the flesh part and the accessory(ies) structure(s) followed by capital letters (in parentheses) that indicate to which structures the preceding colours refer to: $\mathrm{A}=$ aril, $\mathrm{B}=$ bracts, $\mathrm{C}=$ capsule, $\mathrm{F}=$ fruit, $\mathrm{P}=$ pedicel, $\mathrm{S}=$ seed, $\mathrm{T}=$ infructescence stem, $\mathrm{Y}=$ calyx; ' ${ }^{\mathrm{C}}$ Seed disperser groups: $\mathrm{a}=\mathrm{bat}, \mathrm{b}=$ bird, $\mathrm{m}=$ monkey, $\mathrm{r}=$ rodent, $\mathrm{s}=$ marsupial, $\mathrm{u}=$ ungulate.

Appendix 2. Mean proportions (based on freshy mass of pulp for water and dry mass for all other components) of the major chemical components of vertebrateddispersed fruits of the Saibadela forest.

\begin{tabular}{|c|c|c|c|c|c|c|}
\hline Family & Species & Water & Lipid & Protein & $\mathrm{TC}^{\mathrm{a}}$ & Ash \\
\hline Annonaceae & Rollinia sericea & 0.90 & 0.09 & 0.06 & 0.79 & 0.06 \\
\hline Araceae & Heteropsis oblongifolia & 0.83 & 0.02 & 0.16 & 0.76 & 0.07 \\
\hline \multirow[t]{2}{*}{ Arecaceae } & Euterpe edulis & 0.69 & 0.20 & 0.08 & 0.70 & 0.03 \\
\hline & Geonoma pauciflora & 0.88 & 0.02 & 0.05 & - & - \\
\hline Boraginaceae & Cordia sylvestris & 0.81 & 0.02 & 0.08 & 0.84 & 0.07 \\
\hline Burseraceae & Protium widgrenii & 0.58 & 0.03 & 0.07 & 0.88 & 0.03 \\
\hline Caesalpinaceae & Copaifera trapezifolia & 0.75 & 0.03 & 0.07 & 0.87 & 0.03 \\
\hline Canellaceae & Cinnamodendron dinizii & 0.75 & 0.16 & 0.09 & 0.70 & 0.05 \\
\hline \multirow[t]{2}{*}{ Cecropiaceae } & Cecropia pachystachia ${ }^{\mathrm{b}}$ & 0.83 & 0.05 & 0.12 & 0.78 & 0.06 \\
\hline & Pourouma guianensis & 0.86 & 0.02 & 0.08 & 0.86 & 0.05 \\
\hline \multirow[t]{3}{*}{ Celastraceae } & Maytenus alanternoides & 0.84 & 0.05 & 0.10 & 0.82 & 0.03 \\
\hline & Maytenus ligustrina & 0.82 & 0.09 & 0.13 & 0.75 & 0.02 \\
\hline & Maytenus robusta & 0.79 & 0.01 & 0.05 & 0.92 & 0.02 \\
\hline Chrysobalanaceae & Parinari excelsa & 0.87 & 0.03 & 0.07 & 0.88 & 0.03 \\
\hline
\end{tabular}

${ }^{\mathrm{a}} \mathrm{TC}=$ Total Carbohydrates; ${ }^{\mathrm{b}}$ species for which seeds were included analyses with the pulp in analysis analyses. 
Appendix 2. Continued...

\begin{tabular}{|c|c|c|c|c|c|c|}
\hline Family & Species & Water & Lipid & Protein & $\mathbf{T C}^{\mathrm{a}}$ & Ash \\
\hline \multirow[t]{2}{*}{ Clusiaceae } & Clusia parviflora & 0.45 & 0.53 & 0.14 & - & - \\
\hline & Garcinia gardneriana & 0.76 & 0.05 & 0.05 & 0.87 & 0.03 \\
\hline Elaeocarpaceae & Sloanea guianensis & 0.91 & 0.03 & 0.07 & 0.88 & 0.03 \\
\hline \multirow[t]{2}{*}{ Euphorbiaceae } & Alchornea triplinervia & 0.43 & 0.68 & 0.08 & 0.22 & 0.02 \\
\hline & Hyeronima alchorneoides & 0.74 & 0.08 & 0.06 & - & - \\
\hline \multirow[t]{2}{*}{ Lauraceae } & Cryptocaria archersoniana & 0.90 & 0.02 & 0.07 & 0.87 & 0.04 \\
\hline & Cryptocaria moschata & 0.85 & 0.04 & 0.08 & 0.84 & 0.04 \\
\hline Marcgraviaceae & Marcgravia polyantha ${ }^{\mathrm{b}}$ & 0.83 & 0.11 & 0.06 & 0.80 & 0.02 \\
\hline Meliaceae & Cabralea canjerana & 0.48 & 0.71 & 0.10 & 0.17 & 0.02 \\
\hline \multirow[t]{3}{*}{ Moraceae } & Ficus insipida $^{\mathrm{b}}$ & 0.87 & 0.06 & 0.07 & 0.81 & 0.06 \\
\hline & Ficus enormis ${ }^{\mathrm{b}}$ & 0.80 & 0.05 & 0.04 & 0.80 & 0.11 \\
\hline & Sorocea bonplandii ${ }^{\mathrm{b}}$ & 0.77 & 0.05 & 0.10 & 0.81 & 0.04 \\
\hline \multirow[t]{2}{*}{ Myristicaceae } & Virola gardneri & 0.72 & 0.89 & 0.05 & 0.05 & 0.01 \\
\hline & Virola bicuhyba & 0.63 & 0.62 & 0.05 & 0.32 & 0.01 \\
\hline \multirow[t]{23}{*}{ Myrtaceae } & Calycorectes australis & 0.94 & 0.07 & 0.19 & 0.67 & 0.07 \\
\hline & Campomansia guaviroba & 0.80 & 0.04 & 0.07 & 0.86 & 0.03 \\
\hline & Campomanesia schlechtendaliana & 0.71 & 0.01 & 0.05 & 0.91 & 0.03 \\
\hline & Campomanesia xanthocarpa & 0.87 & 0.04 & 0.09 & 0.83 & 0.04 \\
\hline & Eugenia cambucarana & 0.81 & 0.01 & 0.07 & 0.89 & 0.03 \\
\hline & Eugenia cuprea & 0.91 & 0.12 & 0.11 & 0.71 & 0.06 \\
\hline & Eugenia melanogyna & 0.83 & 0.03 & 0.05 & 0.87 & 0.05 \\
\hline & Eugenia mosenii & 0.82 & 0.03 & 0.04 & 0.88 & 0.05 \\
\hline & Eugenia multicostata & 0.81 & 0.03 & 0.08 & 0.86 & 0.03 \\
\hline & Eugenia neoglomerata & 0.79 & 0.02 & 0.06 & 0.88 & 0.04 \\
\hline & Eugenia neoverrucosa & 0.82 & 0.07 & 0.15 & 0.72 & 0.06 \\
\hline & Eugenia oblongata & 0.91 & 0.19 & 0.09 & 0.67 & 0.05 \\
\hline & Eugenia riedeliana & 0.86 & 0.14 & 0.15 & 0.65 & 0.06 \\
\hline & Eugenia stictosepala & 0.78 & 0.05 & 0.08 & 0.83 & 0.04 \\
\hline & Gomidesia anacardifolia & 0.85 & 0.03 & 0.10 & 0.83 & 0.04 \\
\hline & Gomidesia flagelaris & 0.88 & 0.02 & 0.08 & 0.86 & 0.04 \\
\hline & Gomidesia spectabilis & 0.76 & 0.06 & 0.06 & 0.84 & 0.04 \\
\hline & Gomidesia tijucensis & 0.80 & 0.02 & 0.05 & 0.90 & 0.03 \\
\hline & Marlierea tomentosa & 0.77 & 0.15 & 0.06 & 0.76 & 0.03 \\
\hline & Myrceugenia myrcioides & 0.86 & 0.06 & 0.09 & 0.80 & 0.05 \\
\hline & Myrceugenia reitzii & 0.75 & 0.08 & 0.09 & 0.77 & 0.06 \\
\hline & Myrcia rostrata & 0.83 & 0.10 & 0.09 & 0.78 & 0.03 \\
\hline & Neomithranthes glomerata & 0.87 & 0.05 & 0.06 & 0.86 & 0.03 \\
\hline Nyctaginaceae & Guapira opposita & 0.68 & 0.03 & 0.19 & 0.72 & 0.06 \\
\hline Olacaceae & Heisteria silvianii & 0.79 & 0.30 & 0.13 & 0.52 & 0.05 \\
\hline Phytolaccaceae & Phytolacca dioica $^{\mathrm{b}}$ & 0.66 & 0.06 & 0.15 & 0.73 & 0.06 \\
\hline Quiinaceae & Quiina glaziovii & 0.87 & 0.08 & 0.03 & 0.70 & 0.20 \\
\hline \multirow[t]{3}{*}{ Rubiaceae } & Coussarea contracta $^{\mathrm{b}}$ & 0.85 & 0.01 & 0.11 & 0.81 & 0.08 \\
\hline & Psychotria mapourioides & 0.89 & 0.04 & 0.09 & 0.87 & 0.04 \\
\hline & Psychotria suterella & 0.71 & 0.08 & 0.03 & 0.84 & 0.06 \\
\hline \multirow[t]{2}{*}{ Sapindaceae } & Cupania oblongifolia & 0.56 & 0.63 & 0.11 & 0.25 & 0.02 \\
\hline & Matayba elaeognoides & - & 0.28 & - & - & - \\
\hline \multirow[t]{2}{*}{ Sapotaceae } & Chrysophyllum viride & 0.83 & 0.04 & 0.10 & 0.82 & 0.05 \\
\hline & Pouteria venosa & 0.75 & 0.11 & 0.09 & 0.77 & 0.04 \\
\hline \multirow[t]{2}{*}{ Verbenaceae } & Citharexylum myrianthum & 0.81 & 0.06 & 0.07 & 0.83 & 0.04 \\
\hline & Vitex sp. & 0.88 & 0.01 & 0.04 & - & - \\
\hline Coefficient of variation $(\%)$ & & 13.7 & 155.6 & 42.5 & 24.8 & 60.6 \\
\hline
\end{tabular}

${ }^{\mathrm{a}} \mathrm{TC}=$ Total Carbohydrates; ${ }^{\mathrm{b}}$ species for which seeds were included analyses with the pulp in analysis analyses. 